$\begin{array}{ll} & \text { Esta obra está sob o direito de } \\ & \text { Licença Creative Commons } \\ & \text { Atribuição 4.0 Internacional. } \\ & \end{array}$

\title{
GESTÃO ESCOLA E PRECARIZAÇÃO NO ENSINO FUNDAMENTAL BÁSICO
}

\author{
Luciano Canuto Jacinto ${ }^{1}$ \\ Lais Agra da Costa ${ }^{2}$ \\ Eliezer José da Silva ${ }^{3}$ \\ Nadson Ribeiro ${ }^{4}$ \\ Divanise Maria de Souza ${ }^{5}$
}

\section{RESUMO}

Objetivo: A fim de identificar as principais problemáticas em torno da precarização na qualidade da educação foi feita uma revisão sistemática integrativa sobre a análise da Gestão Escolar no ensino fundamental básico. Método: Trata-se de uma revisão sistemática integrativa. Os descritores estruturados no DECS e MESH e educação, foram utilizados na varredura da base de busca do Periódico Capes e SCIELO. A coleta de dados se deu no período dos meses de fevereiro a maio de 2020. Adotaram-se como critérios de inclusão: artigos de opiniões de especialistas e resenhas. Portanto, os critérios de exclusão foram: artigos e dissertações que não contemplaram a temática sobre a análise do SAEB e IDEB na qualidade e precarização da educação básica pública. Resultados: A busca resultou em 451 publicações cientificas, das quais 31 eram artigos científicos disponíveis após aplicação dos filtros, e destes 21 trabalhos obedeceram aos critérios de inclusão, sendo submetidos às etapas da revisão integrativa. As categorias temáticas desenvolvidas a partir da análise dos trabalhos foram: A gestão escolar, a precarização e/ou qualidade do ensino, assim como os índices avaliativos da educação básica brasileira. Conclusão: A falta de objetividade nas ações de políticas públicas, o indevido acesso à infraestrutura necessária, que colabore no processo de inclusão -e acessibilidade das condições sociais inseridas, causam a deficiência pedagógica no ensino. Assim, caracterizadas em um quadro de ineficiência no aprendizado, destarte, como consequência uma qualidade regular na formação inicial dos educandos.

Palavras-chave: Gestão Escolar, Educação Básica, Qualidade na Educação.

Submetido em junho de 2020 e aceito em setembro de 2020.

\footnotetext{
${ }^{1}$ lucianocanutojacinto11@gmail.com

2 laiscostaagra@gmail.com

3 eliezer.j.s@outlook.com

4 ribeironadson@hotmail.com

5 divanisemaria@hotmail.com
} 
Rev. Científica Evidência, Maceió, v. 3, n.1, p. 29-61, jul/set, 2020

\section{INTRODUÇÃO}

Este artigo tem como objetivo detectar os vetores da gestão escolar na qualidade da educação básica e apresentar a relação de significância dos índices de avaliação como IDEB e SAEB. Tendo em vista, que o país hoje sofre constantes mudanças pedagógicas temos que a educação sempre foi e será essencial na vida e desenvolvimento do ser humano. Igualmente, o indivíduo nas séries iniciais de aprendizado tende a absorver melhor o que lhes é ensinado, assim a excelência, seja no suporte pedagógico ou atenção por parte dos gestores escolares faz toda a diferença para estimular os meios cognitivos do educando.

Entretanto, mesmo diante dos problemas enfrentados no sistema educacional brasileiro, sabemos que sem educação não há como exercer a cidadania de forma plena. Nesse contexto, temos que a gestão educacional segue as orientações determinam pela Lei 9.394/96 que define que a educação básica tem por finalidades desenvolver o educando, assegurando-lhe a formação comum indispensável para 0 exercício da cidadania e fornecendo-lhe meios para progredir no trabalho e em estudos posteriores (REFERÊNCIA DA LEI). O exposto na mesma, estabelece o modelo democrático e participativo da administração escolar.

Um importante instrumento a contribuir com o processo educacional são os Índices de avaliação do Desenvolvimento da Educação Básica (IDEB) que é um aferidor dos avanços de conhecimento do alunado. Bem como, o Sistema de Avaliação da Educação Básica (SAEB) que é um conjunto de avaliações que permite ao Instituto Nacional de Estudos e Pesquisas Educacionais (INEP) realizar uma diagnose da educação básica brasileira, qualificando desempenho dos discentes.

Assim, teve como objetivo através da revisão sistemática integrativa, observar a real situação da educação básica brasileira através da análise da gestão escolar no ensino fundamental básico. Tendo a seguinte pergunta norteadora: Há qualidade ou precarização no ensino básico brasileiro? Contudo, as temáticas foram abordadas de acordo como os artigos selecionados. Entender os conceitos educacionais relacionados a gestão escolar e como a mesma influência na qualidade do ensino da educação básica pública brasileira, bem como as avaliações do SAEB e IDEB abordam a qualidade de ensino e quais as principais dificuldades encontradas no trabalho educacional brasileiro serão temas abordados nessa revisão. 
Rev. Científica Evidência, Maceió, v. 3, n.1, p. 29-61, jul/set, 2020

\section{METODOLOGIA}

Trata-se de uma revisão de literatura tradicional, não sistemática, descritiva, de natureza qualitativa, com análise de conteúdo de livros e documentos adquiridos em bibliotecas físicas e virtuais. As categorias temáticas desenvolvidas após análise dos conteúdos foram: homossexualismo e religião: um longo caminho de mudança de postura; posição da igreja católica frente ao homossexualismo; a bíblia e o homossexualismo.

A metodologia utilizada versa de uma revisão bibliográfica, do tipo sistemática integrativa, que seguiu as seguintes etapas (Figura 1): definição do tema; seleção da pergunta norteadora e escolha da estratégia de busca; descritores e bases de dados mais eficazes no levantamento das publicações; escolha dos critérios de inclusão e exclusão; identificação dos estudos pré-selecionados e selecionados por meio da leitura dos agentes indexadores das publicações, como resumos, palavras-chave e títulos, bem como a organização dos estudos préselecionados e a identificação dos estudos selecionados; categorização dos estudos selecionados, com a elaboração e o uso da matriz de síntese, além da análise das informações; a formação de uma biblioteca individual e a avaliação crítica dos estudos selecionados; análise, interpretação e discussão dos resultados e a apresentação da revisão em formato de artigo, o qual contempla as propostas para estudos futuros.

Quadro 1 - Detalhamento das etapas da Revisão Sistemática Integrativa.

\begin{tabular}{|c|c|c|}
\hline ETAPA & $\begin{array}{l}\text { TÓPICOS DE CADA } \\
\text { ETAPA }\end{array}$ & DETALHAMENTO DE CADA TÓPICO \\
\hline \multirow[t]{6}{*}{$1^{\mathrm{a}}$} & Tema & Gestão escolar e precarização no ensino básico. \\
\hline & Pergunta norteadora & $\begin{array}{l}\text { Há qualidade ou precarização no ensino básico } \\
\text { brasileiro? }\end{array}$ \\
\hline & Objetivo geral & $\begin{array}{l}\text { Identificar, através da revisão sistemática integrativa, a } \\
\text { qualidade na gestão escolar e a precarização na } \\
\text { educação básica. }\end{array}$ \\
\hline & Estratégia de busca & $\begin{array}{l}\text { Cruzamento de descritores, quando necessário, por } \\
\text { meio do operador boleano AND; } \\
\text { Uso de descritores estruturados (codificação no DECS } \\
\text { ou MESH. } \\
\text { Uso de metadados (filttros) nas bibliotecas virtuais; } \\
\text { Uso de aspas nos politermos, para que a varredura de } \\
\text { artigos científicos contemplasse o termo exato } \\
\text { Uso de descritores em português }\end{array}$ \\
\hline & $\begin{array}{l}\text { Descritores estruturados no } \\
\text { DECS e MASH e livres. }\end{array}$ & 1. educação (DECS 4562), (MASH D04493); \\
\hline & Bibliotecas Virtuais & Periódico Capes Scielo \\
\hline $2^{\mathrm{a}}$ & Período de coleta dos dados & Fevereiro á Maio de 2020. \\
\hline
\end{tabular}


Rev. Científica Evidência, Maceió, v. 3, n.1, p. 29-61, jul/set, 2020

\begin{tabular}{|c|c|c|}
\hline & Critérios de inclusão & $\begin{array}{l}\text { Texto (artigo de opinião de especialista, ou } \\
\text { dissertações). Publicação (2016-2020). }\end{array}$ \\
\hline & Critérios de exclusão & $\begin{array}{l}\text { 1.Artigos ou dissertações que não contemplam a } \\
\text { temática gestão escolar e precarização no ensino } \\
\text { fundamental básico. } \\
\text { 2. Artigos não revisados por pares. } \\
\text { 3. Artigos que não estão em português. }\end{array}$ \\
\hline $3^{a}$ & $\begin{array}{l}\text { Número de trabalhos } \\
\text { selecionados para revisão } \\
\text { sistemática integrativa a } \\
\text { partir da leitura dos agentes } \\
\text { indexadores das publicações } \\
\text { (resumo, palavras-chave e } \\
\text { título) e resultados, os quais } \\
\text { devem conter os descritores } \\
\text { utilizados nesse estudo. }\end{array}$ & 21 trabalhos \\
\hline $4^{\mathrm{a}}$ & $\begin{array}{l}\text { Categorias obtidas com a } \\
\text { análise dos trabalhos } \\
\text { científicos investigados. }\end{array}$ & \\
\hline $5^{a}$ & $\begin{array}{l}\text { Analise, interpretação e } \\
\text { discursão dos resultados }\end{array}$ & Ver em "Resultados e Discussão" \\
\hline
\end{tabular}

Fonte: Elaborada pelos autores.

\section{RESULTADOS E DISCUSSÃO}

O Quadro 2 trata do total de documentos disponíveis na Plataforma
Periódico Capes e Scielo obtidos por string de busca.

Quadro 2 - Total de artigos selecionados.

\begin{tabular}{|l|l|l|l|l|l|}
\hline \multicolumn{1}{|c|}{ String de busca } & \multicolumn{1}{|c|}{$\begin{array}{c}\text { Bases de } \\
\text { dados } \\
\text { publicações }\end{array}$} & $\begin{array}{l}\text { Publicações após } \\
\text { aplicação dos } \\
\text { filtros }\end{array}$ & $\begin{array}{c}\text { Publicações } \\
\text { selecionadas }\end{array}$ \\
\hline $\begin{array}{l}\text { Gestão Escolar and } \\
\text { Educação }\end{array}$ & $\begin{array}{l}\text { Plataforma } \\
\text { Periódico } \\
\text { Capes }\end{array}$ & 741 & 59 & 8 \\
\hline $\begin{array}{l}\text { Gestão Escolar and } \\
\text { Educação Básica }\end{array}$ & $\begin{array}{l}\text { Plataforma } \\
\text { Periódico } \\
\text { Capes }\end{array}$ & 691 & 229 & 1 \\
\hline $\begin{array}{l}\text { Gestão Escolar or } \\
\text { Educação Básica }\end{array}$ & $\begin{array}{l}\text { Plataforma } \\
\text { Periódico } \\
\text { Capes }\end{array}$ & 39 & 1 & 2 \\
\hline $\begin{array}{l}\text { Gestão Escolar and } \\
\text { Educação }\end{array}$ & $\begin{array}{l}\text { Scielo } \\
\text { Gestão Escolar and }\end{array}$ & Scielo & 48 & 57 & 5 \\
\hline Educação Básica & & 12 & \\
\hline
\end{tabular}


Rev. Científica Evidência, Maceió, v. 3, n.1, p. 29-61, jul/set, 2020

\begin{tabular}{|l|l|l|l|l|}
\hline $\begin{array}{l}\text { Gestão Escolar or } \\
\text { Educação Básica }\end{array}$ & Scielo & 610 & 93 & 3 \\
\hline Total & & & 451 & 21 \\
\hline
\end{tabular}

FONTE: Elaborado pelo autor.

Foram detectadas 451 publicações de carácter científico nos bancos de dados, das quais 31 eram artigos científicos disponíveis após o uso dos filtros, desses foram feitos 21 downloads, que obedeceram aos critérios de inclusão (Quadro 2), sendo submetidos às etapas da revisão integrativa (Quadro 3).

Quadro 3 - Descrição dos documentos (artigos) de acordo com os critérios de inclusão.

\begin{tabular}{|c|c|c|c|c|c|c|}
\hline $\mathbf{N}^{\mathbf{o}}$ & Autor(a) & Tema & $\begin{array}{c}\text { Link da } \\
\text { publicação }\end{array}$ & Descritores & $\begin{array}{c}\text { Data de } \\
\text { publicaç } \\
\text { ão }\end{array}$ & Conclusão \\
\hline 1 & $\begin{array}{l}\text { TORRES, } \\
\text { Haroldo da } \\
\text { Gama; } \\
\text { CAMELO, } \\
\text { Rafael; } \\
\text { CASTRO, } \\
\text { Maria } \\
\text { Helena } \\
\text { Guimarães }\end{array}$ & $\begin{array}{l}\text { Dificul } \\
\text { dades } \\
\text { de } \\
\text { Coorde } \\
\text { nação e } \\
\text { Política } \\
\text { s } \\
\text { Educac } \\
\text { ionais } \\
\text { no } \\
\text { Brasil: } \\
\text { O Caso } \\
\text { do } \\
\text { Ensino } \\
\text { Funda } \\
\text { mental. }\end{array}$ & $\begin{array}{l}\text { <http://ww } \\
\text { w.scielo.br/ } \\
\text { scielo.php? } \\
\text { script=sci_- } \\
\text { arttext\&pid } \\
=\text { S0011- } \\
525820190 \\
00400200 \\
\& 1 n g=\text { en\& } \\
\text { nrm=iso>. } \\
\text { access } \\
\text { on 14 Ma } \\
\text { y 2020. E } \\
\text { pub Nov } 14 \\
\text { 2019. https } \\
: / / \text { doi.org/1 } \\
0.1590 / 001 \\
152582019 \\
\text { 190. }\end{array}$ & $\begin{array}{l}\text { Educação; } \\
\text { Steiner; } \\
\text { Pensar } \\
\text { Vivenciado }\end{array}$ & 2019 & $\begin{array}{l}\text { Em suma, há } \\
\text { problemas de } \\
\text { coordenação. O } \\
\text { cenário hoje continua } \\
\text { sendo o de limitada } \\
\text { coordenação de ações } \\
\text { entre o MEC e os } \\
\text { estados; entre o } \\
\text { estado e seus } \\
\text { municípios; entre o } \\
\text { MEC e os } \\
\text { municípios; e - em } \\
\text { vários casos - entre o } \\
\text { gestor municipal ou } \\
\text { estadual e sua própria } \\
\text { rede. Há também } \\
\text { problemas de falta de } \\
\text { articulação entre os } \\
\text { técnicos das } \\
\text { secretarias em todos } \\
\text { os níveis de ensino e } \\
\text { entre diferentes } \\
\text { agências federais e } \\
\text { locais. Na prática, } \\
\text { isso significa que a } \\
\text { gestão administrativa } \\
\text { e pedagógica da } \\
\text { educação funciona de } \\
\text { modo limitado e } \\
\text { faltam mecanismos } \\
\text { de coordenação entre } \\
\text { os níveis de governo. } \\
\text { Sem dúvida, esse } \\
\text { parece ser um tema } \\
\text { de extrema relevância }\end{array}$ \\
\hline
\end{tabular}




\begin{tabular}{|c|c|c|c|c|c|c|}
\hline & & & & & & $\begin{array}{l}\text { para as políticas de } \\
\text { ensino básico no } \\
\text { futuro próximo. }\end{array}$ \\
\hline 2 & $\begin{array}{l}\text { PASCHO } \\
\text { ALINO, } \\
\text { Jussara } \\
\text { Bueno de } \\
\text { Queiroz. }\end{array}$ & $\begin{array}{l}\text { Gestão } \\
\text { Escolar } \\
\text { na } \\
\text { Educaç } \\
\text { ão } \\
\text { Básica: } \\
\text { constru } \\
\text { ções e } \\
\text { estratég } \\
\text { ias } \\
\text { frente } \\
\text { aos } \\
\text { desafio } \\
\text { s } \\
\text { profissi } \\
\text { onais. }\end{array}$ & $\begin{array}{l}\text { http://www } \\
\text {.scielo.br/s } \\
\text { cielo.php?s } \\
\text { cript=sci_a } \\
\text { rttext\&pid= } \\
\text { S2175- } \\
623620180 \\
00401301 \\
\& 1 n g=p t \& n \\
\text { rm=iso> }\end{array}$ & $\begin{array}{l}\text { Gestão } \\
\text { Escolar; } \\
\text { Educação } \\
\text { Básica; } \\
\text { Desafios } \\
\text { Profissionais. }\end{array}$ & 2018 & $\begin{array}{l}\text { Dessa maneira, o } \\
\text { discurso engendrado } \\
\text { traz a perspectiva de } \\
\text { que essa nova } \\
\text { dinâmica de } \\
\text { acompanhamento dos } \\
\text { supervisores torna } \\
\text { mais fácil } \\
\text { potencializar a ação } \\
\text { diretiva, com a } \\
\text { identificação dos } \\
\text { pontos fortes e a } \\
\text { correção dos pontos } \\
\text { fracos. Essa proposta } \\
\text { é nova e apenas } \\
\text { poucos passos foram } \\
\text { dados até agora para } \\
\text { fazer frente às } \\
\text { diversas demandas do } \\
\text { gestor escolar. Assim, } \\
\text { será necessário } \\
\text { acompanhar o } \\
\text { trabalho iniciado pela } \\
\text { Prefeitura do Rio de } \\
\text { Janeiro para avaliar } \\
\text { se ele cumprirá seu } \\
\text { objetivo de fortalecer } \\
\text { a formação dos } \\
\text { gestores escolares. }\end{array}$ \\
\hline 3 & $\begin{array}{l}\text { ABDIAN, } \\
\text { Graziela } \\
\text { Zambão; } \\
\text { NASCIME } \\
\text { NTO, } \\
\text { Paulo } \\
\text { Henrique } \\
\text { Costa; } \\
\text { SILVA, } \\
\text { Nathália } \\
\text { Delgado } \\
\text { Bueno da }\end{array}$ & $\begin{array}{l}\text { DESA } \\
\text { FIOS } \\
\text { TEÓRI } \\
\text { CO- } \\
\text { METO } \\
\text { DOLÓ } \\
\text { GICOS } \\
\text { PARA } \\
\text { AS } \\
\text { PESQ } \\
\text { UISAS } \\
\text { EM } \\
\text { ADMI } \\
\text { NISTR } \\
\text { AÇÃO/ } \\
\text { GEST } \\
\tilde{\text { AO }} \\
\text { EDUC } \\
\text { ACIO } \\
\text { NAL/E } \\
\text { SCOL } \\
\text { AR. }\end{array}$ & $\begin{array}{l}\text { http://www } \\
\text {.scielo.br/s } \\
\text { cielo.php?s } \\
\text { cript=sci_a } \\
\text { rttext\&pid= } \\
\text { S0101- } \\
733020160 \\
00200465 \\
\& 1 n g=\text { en\& } \\
\text { nrm=iso }\end{array}$ & $\begin{array}{l}\text { Administração } \\
\text { escolar. } \\
\text { Gestão } \\
\text { escolar. } \\
\text { Desafios } \\
\text { teórico } \\
\text { metodológico } \\
\text { s. }\end{array}$ & 2016 & $\begin{array}{l}\text { Nesse sentido, } \\
\text { podemos "contribuir } \\
\text { para um acréscimo de } \\
\text { lucidez por parte de } \\
\text { todos os atores } \\
\text { sociais envolvidos no } \\
\text { campo da educação" } \\
\text { e "renunciando à } \\
\text { produção de um } \\
\text { discurso fundado na } \\
\text { previsão ou na } \\
\text { prescrição", } \\
\text { buscarmos construir } \\
\text { um "conhecimento } \\
\text { que permita ajudar os } \\
\text { atores sociais a } \\
\text { organizar de outras } \\
\text { maneiras as suas } \\
\text { interações" } \\
\text { (CANÁRIO, 2006, p. } \\
\text { 155). }\end{array}$ \\
\hline
\end{tabular}


Rev. Científica Evidência, Maceió, v. 3, n.1, p. 29-61, jul/set, 2020

\begin{tabular}{|c|c|c|c|c|c|c|}
\hline 4 & $\begin{array}{l}\text { Silva da } \\
\text { Costa, E. } \\
\text { (1). }\end{array}$ & $\begin{array}{l}\text { Gestão } \\
\text { escolar } \\
\text { e } \\
\text { IDEB: } \\
\text { propost } \\
\text { as e } \\
\text { suas } \\
\text { relaçõe } \\
\text { s para o } \\
\text { crescim } \\
\text { ento do } \\
\text { índice } \\
\text { de } \\
\text { desenv } \\
\text { olvime } \\
\text { nto da } \\
\text { Educaç } \\
\text { ão } \\
\text { Básica } \\
\text { dos } \\
\text { Anos } \\
\text { Finais } \\
\text { do } \\
\text { Ensino } \\
\text { Funda } \\
\text { mental } \\
\text { nas } \\
\text { Escolas } \\
\text { Munici } \\
\text { pais de } \\
\text { Parago } \\
\text { minas/ } \\
\text { PA- } \\
\text { Brasil. }\end{array}$ & $\begin{array}{l}\text { https://revis } \\
\text { taselectroni } \\
\text { cas.ujaen.e } \\
\text { s/index.php } \\
\text { /riai/article/ } \\
\text { view/4316 }\end{array}$ & $\begin{array}{l}\text { Gestão; } \\
\text { Índice; } \\
\text { Crescimento; } \\
\text { Desenvolvime } \\
\text { nto; } \\
\text { Educação. }\end{array}$ & 2018 & $\begin{array}{l}\text { Portanto, apesar de } \\
\text { todas as estratégias e } \\
\text { práticas utilizadas por } \\
\text { todos os educadores o } \\
\text { crescimento não foi } \\
\text { efetivo, mais é } \\
\text { preciso ter a } \\
\text { expectativa que as } \\
\text { culturas organizativas } \\
\text { das escolas } \\
\text { delinearão caminhos } \\
\text { ainda mais úteis e } \\
\text { consistentes para uma } \\
\text { melhor evolução do } \\
\text { conhecimento, mais } \\
\text { para isso, é preciso } \\
\text { ainda mais um maior } \\
\text { comprometimento de } \\
\text { toda a sociedade e de } \\
\text { todos os gestores, } \\
\text { somente dessa forma } \\
\text { será eficaz a } \\
\text { qualidade do ensino } \\
\text { em nosso País. }\end{array}$ \\
\hline 5 & $\begin{array}{l}\text { Da Costa, } \\
\text { R. V. } \\
\text { (2020). }\end{array}$ & $\begin{array}{l}\text { Gestão } \\
\text { Democ } \\
\text { rática: } \\
\text { função } \\
\text { admini } \\
\text { strativa } \\
\text { pedagó } \\
\text { gica e a } \\
\text { atuação } \\
\text { finance } \\
\text { ira dos } \\
\text { gestore } \\
\text { s nas } \\
\text { escolas } \\
\text { de } \\
\text { Sinop/ } \\
\text { MT- } \\
\text { Brasil. }\end{array}$ & $\begin{array}{l}\text { https://revis } \\
\text { taselectroni } \\
\text { cas.ujaen.e } \\
\text { s/index.php } \\
\text { /riai/article/ } \\
\text { view/5192 }\end{array}$ & $\begin{array}{l}\text { gestão } \\
\text { escolar; } \\
\text { administração } \\
\text { pedagógica; } \\
\text { funções } \\
\text { administrativa } \\
\text { s; prática } \\
\text { educativa; } \\
\text { gestão } \\
\text { democrática }\end{array}$ & 2019 & $\begin{array}{l}\text { Finalmente, } \\
\text { comprovamos que } \\
\text { nosso objetivo geral } \\
\text { de analisar se a } \\
\text { gestão escolar } \\
\text { dos gestores em } \\
\text { quanto às distintas } \\
\text { funções } \\
\text { administrativas, } \\
\text { pedagógica e } \\
\text { financeira, } \\
\text { estão pautadas no } \\
\text { princípio da Gestão } \\
\text { democrática, estão } \\
\text { comprovadas, } \\
\text { que o papel do gestor } \\
\text { é maior do que } \\
\text { pensávamos no início } \\
\text { da pesquisa, os } \\
\text { investigados } \\
\text { acreditam que cabe à }\end{array}$ \\
\hline
\end{tabular}




\begin{tabular}{|c|c|c|c|c|c|c|}
\hline & & & & & & $\begin{array}{l}\text { equipe gestora } \\
\text { proporcionar espaços } \\
\text { de participação e, } \\
\text { dentre outras } \\
\text { competências, } \\
\text { promover um clima } \\
\text { de confiança e } \\
\text { reciprocidade, em } \\
\text { que todos possam } \\
\text { compartilhar ideias, } \\
\text { opiniões, e assim, } \\
\text { efetivar uma gestão } \\
\text { democrática que seja } \\
\text { realizado juntamente } \\
\text { com a comunidade } \\
\text { escolar. }\end{array}$ \\
\hline 6 & $\begin{array}{l}\text { FREITAS } \\
\text {, Dirce } \\
\text { Nei } \\
\text { Teixeira } \\
\text { de. }\end{array}$ & $\begin{array}{l}\text { AVALI } \\
\text { AÇÃO } \\
\text { E } \\
\text { GEST } \\
\tilde{A} O \\
\text { DEMO } \\
\text { CRÁTI } \\
\text { CA NA } \\
\text { REGU } \\
\text { LAÇÃ } \\
\text { O DA } \\
\text { EDUC } \\
\text { AÇÃO } \\
\text { BÂSIC } \\
\text { A } \\
\text { BRASI } \\
\text { LEIRA } \\
\text { : UMA } \\
\text { RELA } \\
\text { ÇÃO A } \\
\text { AVALI } \\
\text { AR }\end{array}$ & $\begin{array}{l}\text { https://ww } \\
\text { w.scielo.br/ } \\
\text { scielo.php? } \\
\text { pid=S0101- } \\
733020070 \\
00200011 \\
\& \text { script=sci } \\
\text { _abstract\&t } \\
\text { lng=pt }\end{array}$ & $\begin{array}{l}\text { Política } \\
\text { educacional. } \\
\text { Gestão } \\
\text { democrática. } \\
\text { Avaliação } \\
\text { educacional. }\end{array}$ & 2007 & $\begin{array}{l}\text { Enfim, o valor e a } \\
\text { utilidade da avaliação } \\
\text { para a gestão } \\
\text { democrática precisam } \\
\text { ser considerados } \\
\text { como critérios de } \\
\text { aferição da } \\
\text { pertinência da } \\
\text { avaliação efetuada. E, } \\
\text { como manifestação } \\
\text { da própria concepção } \\
\text { de gestão } \\
\text { democrática } \\
\text { prevalecente, pode } \\
\text { essa prática, } \\
\text { examinada em seu } \\
\text { valor e utilidade, } \\
\text { revelar e orientar } \\
\text { escolhas relativas à } \\
\text { vivência democrática } \\
\text { na educação }\end{array}$ \\
\hline 7 & $\begin{array}{l}\text { FRANCO, } \\
\text { Creso; AL } \\
\text { VES, } \\
\text { Fátima; Bo } \\
\text { namino, } \\
\text { Alicia. }\end{array}$ & $\begin{array}{l}\text { QUALI } \\
\text { DADE } \\
\text { DO } \\
\text { ENSIN } \\
\text { O } \\
\text { FUND } \\
\text { AMEN } \\
\text { TAL: } \\
\text { POLÍT } \\
\text { ICAS, } \\
\text { SUAS } \\
\text { POSSI } \\
\text { BILID } \\
\text { ADES, } \\
\text { SEUS }\end{array}$ & $\begin{array}{l}\text { https://ww } \\
\text { w.scielo.br/ } \\
\text { scielo.php? } \\
\text { pid=S0101- } \\
733020070 \\
00300017 \\
\text { \&script=sci } \\
\text { abstract\&t } \\
\text { lng=pt }\end{array}$ & $\begin{array}{l}\text { Política } \\
\text { educacional. } \\
\text { Ensino } \\
\text { fundamental. } \\
\text { Qualidade da } \\
\text { educação. } \\
\text { Racionalidade } \\
\text { técnica. } \\
\text { Racionalidade } \\
\text { substantiva. }\end{array}$ & 2007 & $\begin{array}{l}\text { Neste contexto, um } \\
\text { desafio para a } \\
\text { pesquisa educacional } \\
\text { é o de compreender, } \\
\text { de modo mais } \\
\text { detalhado, os méritos } \\
\text { relativos das teorias } \\
\text { identitárias e de ação } \\
\text { racional na } \\
\text { compreensão das } \\
\text { ações dos agentes em } \\
\text { educação. } \\
\text { Complementarmente, } \\
\text { gestores educacionais } \\
\text { têm o desafio de } \\
\text { desenhar políticas em }\end{array}$ \\
\hline
\end{tabular}




\begin{tabular}{|c|c|c|c|c|c|c|}
\hline & & $\begin{array}{l}\text { LIMIT } \\
\text { ES }\end{array}$ & & & & $\begin{array}{l}\text { prol da qualidade e da } \\
\text { eqüidade em } \\
\text { educação que } \\
\text { compatibilizem } \\
\text { incentivos com as } \\
\text { estratégias } \\
\text { identitárias dos } \\
\text { docentes. }\end{array}$ \\
\hline 8 & $\begin{array}{l}\text { Elton Luiz } \\
\text { Nardi, } \\
\text { Marilda } \\
\text { Pasqual } \\
\text { Schneider, } \\
\text { Mônica } \\
\text { Piccione } \\
\text { Gomes } \\
\text { Rios }\end{array}$ & $\begin{array}{l}\text { Qualid } \\
\text { ade na } \\
\text { Educaç } \\
\text { ão } \\
\text { Básica: } \\
\text { ações e } \\
\text { estratég } \\
\text { ias } \\
\text { dinami } \\
\text { zadoras }\end{array}$ & $\begin{array}{l}\text { https://ww } \\
\text { w.scielo.br/ } \\
\text { scielo.php? } \\
\text { script=sci_ } \\
\text { arttext\&pid } \\
=\text { S2175- } \\
623620140 \\
00200003 \\
\& \operatorname{lng}=\mathrm{pt} \& n \\
\text { rm=iso\&tln } \\
\mathrm{g}=\mathrm{pt}\end{array}$ & $\begin{array}{l}\text { Qualidade da } \\
\text { Educação } \\
\text { Básica. Ações } \\
\text { e Estratégias. } \\
\text { Índices e } \\
\text { Indicadores } \\
\text { Oficiais. }\end{array}$ & 2014 & $\begin{array}{l}\text { A confirmar-se a } \\
\text { tendência de, a } \\
\text { despeito do projeto } \\
\text { educativo da escola, a } \\
\text { meta central ser a de } \\
\text { atender aos índices e } \\
\text { indicadores oficiais, } \\
\text { corre-se o risco de } \\
\text { que os resultados } \\
\text { tenham um fim em si } \\
\text { mesmo, sem } \\
\text { assegurar avanços } \\
\text { efetivos na qualidade } \\
\text { da educação. Por } \\
\text { isso, avançar rumo à } \\
\text { articulação entre os } \\
\text { processos de } \\
\text { autoavaliação } \\
\text { institucional, } \\
\text { avaliação externa e } \\
\text { avaliação da } \\
\text { aprendizagem, } \\
\text { conforme propõem } \\
\text { Freitas e outros } \\
\text { (2011), parece-nos } \\
\text { um caminho coerente } \\
\text { na perspectiva da } \\
\text { construção de uma } \\
\text { educação de } \\
\text { qualidade } \\
\text { socialmente } \\
\text { referenciada, para o } \\
\text { que também é } \\
\text { necessária a } \\
\text { apropriação } \\
\text { diagnóstica, pela } \\
\text { escola, dos índices e } \\
\text { indicadores } \\
\text { educacionais oficiais. } \\
\text { Em um contexto que } \\
\text { informa o reforço da } \\
\text { posição do Ideb como } \\
\text { principal referência } \\
\text { no monitoramento da } \\
\text { qualidade da } \\
\text { educação básica } \\
\text { brasileira, a despeito }\end{array}$ \\
\hline
\end{tabular}




\begin{tabular}{|c|c|c|c|c|c|c|}
\hline & & & & & & $\begin{array}{l}\text { da complexidade de } \\
\text { fatores e elementos } \\
\text { que envolvem a } \\
\text { qualidade enquanto } \\
\text { produto histórico e } \\
\text { social que reflete } \\
\text { posicionamentos } \\
\text { políticos e } \\
\text { ideológicos (Barretto, } \\
\text { 2001), a articulação } \\
\text { aqui destacada } \\
\text { representa, sem } \\
\text { dúvida, um desafio a } \\
\text { ser enfrentado. }\end{array}$ \\
\hline 9 & $\begin{array}{l}\text { DOURA } \\
\text { DO, Luiz } \\
\text { Fernandes } \\
\text { and OLI } \\
\text { VEIRA, } \\
\text { João } \\
\text { Ferreira } \\
\text { de. }\end{array}$ & $\begin{array}{l}\text { A } \\
\text { qualida } \\
\text { de da } \\
\text { educaç } \\
\text { ão: pers } \\
\text { pectiva } \\
\text { s e } \\
\text { desafio } \\
\text { s. }\end{array}$ & $\begin{array}{l}\text { https://ww } \\
\text { w.scielo.br/ } \\
\text { scielo.php? } \\
\text { pid=S0101- } \\
\text { 326220090 } \\
00200004 \\
\& \text { script=sci } \\
\text { _abstract\&t } \\
\text { lng=pt }\end{array}$ & $\begin{array}{l}\text { Qualidade da } \\
\text { educação; } \\
\text { Educação } \\
\text { básica; } \\
\text { Dimensões } \\
\text { intra e } \\
\text { extraescolares } \\
\text { · }\end{array}$ & 2019 & $\begin{array}{l}\text { À guisa de conclusão, } \\
\text { destacam-se, a seguir, } \\
\text { alguns aspectos } \\
\text { fundamentais } \\
\text { concernentes à } \\
\text { construção de um } \\
\text { movimento nacional } \\
\text { em prol da qualidade } \\
\text { da educação. Nesse } \\
\text { sentido, entende-se } \\
\text { que: } \\
\text { a) as dimensões, intra } \\
\text { e extraescolares, } \\
\text { devem ser } \\
\text { consideradas de } \\
\text { maneira articulada na } \\
\text { efetivação de uma } \\
\text { política educacional } \\
\text { direcionada à garantia } \\
\text { de escola de } \\
\text { qualidade para todos, } \\
\text { em todos os níveis e } \\
\text { modalidades; b) a } \\
\text { construção de uma } \\
\text { escola de qualidade } \\
\text { deve considerar a } \\
\text { dimensão } \\
\text { socioeconômica e } \\
\text { cultural, uma vez que } \\
\text { o ato educativo } \\
\text { escolar se dá em um } \\
\text { contexto de posições } \\
\text { e disposições no } \\
\text { espaço social (de } \\
\text { conformidade com o } \\
\text { acúmulo de capital } \\
\text { econômico, social e } \\
\text { cultural dos sujeitos- } \\
\text { usuários da escola), } \\
\text { de heterogeneidade e } \\
\text { pluralidade }\end{array}$ \\
\hline
\end{tabular}




\begin{tabular}{|c|c|c|c|c|c|c|}
\hline & & & & & & $\begin{array}{l}\text { sociocultural, de } \\
\text { problemas sociais que } \\
\text { repercutem na escola, } \\
\text { tais como fracasso } \\
\text { escolar, } \\
\text { desvalorização social } \\
\text { dos segmentos menos } \\
\text { favorecidos, } \\
\text { incluindo a } \\
\text { autoestima dos alunos } \\
\text { etc.; (...) }\end{array}$ \\
\hline 10 & $\begin{array}{l}\text { MARCH } \\
\text { ELLI, } \\
\text { Paulo } \\
\text { Sérgio. }\end{array}$ & $\begin{array}{l}\text { Expans } \\
\text { ão e } \\
\text { qualida } \\
\text { de da } \\
\text { educaç } \\
\text { ão } \\
\text { básica } \\
\text { no } \\
\text { Brasil. }\end{array}$ & $\begin{array}{l}\text { https://ww } \\
\text { w.scielo.br/ } \\
\text { scielo.php? } \\
\text { pid=S0100- } \\
157420100 \\
00200013 \\
\text { \&script=sci } \\
\text { abstract\&t } \\
\text { lng=pt }\end{array}$ & $\begin{array}{l}\text { avaliação da } \\
\text { educação; } \\
\text { políticas } \\
\text { educacionais; } \\
\text { qualidade do } \\
\text { ensino; dados } \\
\text { estatísticos. }\end{array}$ & 2010 & $\begin{array}{l}\text { Se forem mal } \\
\text { interpretados, os } \\
\text { déficits de } \\
\text { aprendizagem } \\
\text { acumulados pelos } \\
\text { alunos da educação } \\
\text { básica brasileira } \\
\text { poderão estimular o } \\
\text { reaparecimento das } \\
\text { políticas de } \\
\text { repetência como } \\
\text { proposta para } \\
\text { melhorar a qualidade } \\
\text { do ensino, perdendo- } \\
\text { se as conquistas } \\
\text { sociais representadas } \\
\text { pela universalização } \\
\text { das matrículas, tão } \\
\text { duramente } \\
\text { conseguidas. Pode-se } \\
\text { dizer que é melhor } \\
\text { um aluno estar } \\
\text { matriculado em uma } \\
\text { escola de má } \\
\text { qualidade do que } \\
\text { ficar fora dela. Isso } \\
\text { não significa que a } \\
\text { busca pela melhoria } \\
\text { da qualidade deixe de } \\
\text { ser perseguida, porém } \\
\text { é preciso encontrar } \\
\text { formas de fazê-lo } \\
\text { sem excluir os } \\
\text { alunos. O Plano de } \\
\text { Desenvolvimento de } \\
\text { Educação } \\
\text { apresentado pelo } \\
\text { MEC em } 2007 \\
\text { representa um } \\
\text { caminho para } \\
\text { promover a desejada } \\
\text { melhoria da } \\
\text { qualidade na escola } \\
\text { sem expurgos sociais, }\end{array}$ \\
\hline
\end{tabular}




\begin{tabular}{|c|c|c|c|c|c|c|}
\hline & & & & & & $\begin{array}{l}\text { mas isso só foi } \\
\text { possível porque seu } \\
\text { principal indicador, o } \\
\text { Ideb, incorporou } \\
\text { definitivamente a } \\
\text { ideia de que a } \\
\text { inclusão escolar é } \\
\text { uma política que não } \\
\text { pode ser abandonada. }\end{array}$ \\
\hline 11 & $\begin{array}{l}\text { FREITAS, } \\
\text { Diretora } \\
\text { Nei } \\
\text { Teixeira } \\
\text { de; OVAN } \\
\text { DO, } \\
\text { Nataly } \\
\text { Gomes. }\end{array}$ & $\begin{array}{l}\text { A } \\
\text { avaliaç } \\
\text { ão } \\
\text { educaci } \\
\text { onal } \\
\text { em } \\
\text { context } \\
\text { os } \\
\text { munici } \\
\text { pais }\end{array}$ & $\begin{array}{l}\text { https://ww } \\
\text { w.scielo.br/ } \\
\text { scielo.php? } \\
\text { pid=S0101- } \\
733020150 \\
00400963 \\
\& \text { script=sci } \\
\text { arttext\&tl } \\
\text { ng=pt }\end{array}$ & $\begin{array}{l}\text { Educação } \\
\text { municipal; } \\
\text { Política } \\
\text { educacional; } \\
\text { Gestão } \\
\text { educacional; } \\
\text { Avaliação } \\
\text { municipal }\end{array}$ & 2015 & $\begin{array}{l}\text { Melhorar os } \\
\text { resultados nas provas } \\
\text { e no Ideb aparecem } \\
\text { como prioridade da } \\
\text { política/gestão } \\
\text { municipal e da } \\
\text { atuação da unidade } \\
\text { escolar. Vemos nisso } \\
\text { uma peculiar forma } \\
\text { de cooperação do } \\
\text { Município com a } \\
\text { União: amálgama de } \\
\text { constrangimento, } \\
\text { assentimento e } \\
\text { recusa, porém sem } \\
\text { que os esforços } \\
\text { municipais deixem de } \\
\text { convergir para que a } \\
\text { política nacional de } \\
\text { melhoria da } \\
\text { qualidade do ensino } \\
\text { fundamental avance } \\
\text { na direção sinalizada } \\
\text { pelo governo federal. } \\
\text { Assim, as respostas } \\
\text { municipais às } \\
\text { iniciativas nacionais } \\
\text { de avaliação e } \\
\text { monitoramento se } \\
\text { dão mediante } \\
\text { cooperação e } \\
\text { tentativas de } \\
\text { preservação da } \\
\text { autonomia municipal. } \\
\text { De todo modo, } \\
\text { difundem a } \\
\text { racionalidade das } \\
\text { políticas e avaliações } \\
\text { educacionais } \\
\text { nacionais. }\end{array}$ \\
\hline 12 & $\begin{array}{l}\text { ALVES, } \\
\text { Wanderso } \\
\text { n Ferreira. }\end{array}$ & $\begin{array}{l}\text { GEST } \\
\tilde{\text { AO }} \\
\text { ESCO } \\
\text { LAR E } \\
\text { O } \\
\text { TRAB }\end{array}$ & $\begin{array}{l}\text { https://ww } \\
\text { w.scielo.br/ } \\
\text { pdf/es/v31n } \\
\text { 110/02.pdf }\end{array}$ & $\begin{array}{l}\text { Trabalho. } \\
\text { Trabalho } \\
\text { docente. } \\
\text { Gestão } \\
\text { escolar. }\end{array}$ & 2010 & $\begin{array}{l}\text { Prolongando um } \\
\text { pouco mais o } \\
\text { pensamento de } \\
\text { Canguilhem, temos } \\
\text { que a relação entre o } \\
\text { homem e o meio }\end{array}$ \\
\hline
\end{tabular}




\begin{tabular}{|c|c|c|c|c|c|c|}
\hline & & $\begin{array}{l}\text { ALHO } \\
\text { DOS } \\
\text { EDUC } \\
\text { ADOR } \\
\text { ES: DA } \\
\text { ESTRE } \\
\text { ITEZA } \\
\text { DAS } \\
\text { POLÍT } \\
\text { ICAS } \\
\text { À } \\
\text { COMP } \\
\text { LEXID } \\
\text { ADE } \\
\text { DO } \\
\text { TRAB } \\
\text { ALHO } \\
\text { HUMA } \\
\text { NO }\end{array}$ & & $\begin{array}{l}\text { Ergonomia. } \\
\text { Ergologia. }\end{array}$ & & $\begin{array}{l}\text { onde desenvolve seu } \\
\text { trabalho comporta } \\
\text { inúmeras } \\
\text { interrogações, não } \\
\text { tendo nada de } \\
\text { evidente ou simples, } \\
\text { a não ser que } \\
\text { acreditemos que o } \\
\text { meio compreende } \\
\text { uma soma de } \\
\text { excitantes, em função } \\
\text { da qual o ser vivo só } \\
\text { faz reagir. Isso não } \\
\text { faz lembrar algumas } \\
\text { ações (pagamento de } \\
\text { bônus...) de nossas } \\
\text { políticas } \\
\text { educacionais? }\end{array}$ \\
\hline 13 & $\begin{array}{l}\text { DIAS, } \\
\text { Nuno } \\
\text { Fernando } \\
\text { de } \\
\text { Carvalho; } \\
\text { MELAO, } \\
\text { Nuno } \\
\text { Filipe } \\
\text { Rosa. }\end{array}$ & $\begin{array}{l}\text { Avaliaç } \\
\text { ão e } \\
\text { Qualid } \\
\text { ade: } \\
\text { Dois } \\
\text { Conceit } \\
\text { os } \\
\text { Indisso } \\
\text { ciáveis } \\
\text { na } \\
\text { Gestão } \\
\text { Escolar }\end{array}$ & $\begin{array}{l}\text { http://www } \\
\text {.scielo.mec. } \\
\text { pt/pdf/tek/n } \\
\text { 12/n12a11. } \\
\text { pdf }\end{array}$ & $\begin{array}{l}\text { Avaliação de } \\
\text { Escolas, } \\
\text { Prestação de } \\
\text { contas, Auto- } \\
\text { avaliação, } \\
\text { Qualidade, } \\
\text { Modelo de } \\
\text { Excelência da } \\
\text { EFQM. }\end{array}$ & 2009 & $\begin{array}{l}\text { Em jeito de } \\
\text { conclusão poderemos } \\
\text { apenas referir que } \\
\text { todo o processo de } \\
\text { autoavaliação deve } \\
\text { ser visto em toda a } \\
\text { comunidade escolar } \\
\text { como o princípio da } \\
\text { procura da qualidade } \\
\text { e, consequentemente, } \\
\text { algo que ninguém } \\
\text { deve ignorar, pois } \\
\text { visa o bem comum. }\end{array}$ \\
\hline 14 & $\begin{array}{l}\text { COELHO, } \\
\text { Maria Inês } \\
\text { de Matos. }\end{array}$ & $\begin{array}{l}\text { Vinte } \\
\text { anos de } \\
\text { avaliaç } \\
\text { ão da } \\
\text { educaç } \\
\text { ão } \\
\text { básica } \\
\text { no } \\
\text { Brasil* } \\
\text { : } \\
\text { aprendi } \\
\text { zagens } \\
\text { e } \\
\text { desafio } \\
\mathrm{s}\end{array}$ & $\begin{array}{l}\text { https://ww } \\
\text { w.scielo.br/ } \\
\text { pdf/ensaio/ } \\
\text { v16n59/v1 } \\
\text { 6n59a05.pd } \\
\text { f }\end{array}$ & $\begin{array}{l}\text { Avaliação de } \\
\text { Sistemas de } \\
\text { Ensino. } \\
\text { Políticas } \\
\text { públicas e } \\
\text { avaliação da } \\
\text { Educação } \\
\text { Básica. } \\
\text { Estado- } \\
\text { avaliador e } \\
\text { Educação. }\end{array}$ & 2008 & $\begin{array}{l}\text { Estão postas novas } \\
\text { questões: Há outra } \\
\text { saída, senão a de } \\
\text { destruir a } \\
\text { individualização? Há } \\
\text { outra saída senão a de } \\
\text { reconstrução das } \\
\text { solidariedades } \\
\text { baseadas na } \\
\text { construção de uma } \\
\text { nova identidade } \\
\text { profissional dos } \\
\text { profissionais da } \\
\text { educação? Há outra } \\
\text { saída senão a de fazer } \\
\text { um novo movimento } \\
\text { de organização e luta } \\
\text { por aspirações e } \\
\text { reivindicações que } \\
\text { historicamente têm } \\
\text { marcado os } \\
\text { profissionais da } \\
\text { educação? }\end{array}$ \\
\hline
\end{tabular}


Rev. Científica Evidência, Maceió, v. 3, n.1, p. 29-61, jul/set, 2020

\begin{tabular}{|c|c|c|c|c|c|c|}
\hline 15 & $\begin{array}{l}\text { FRANCO, } \\
\text { Creso. }\end{array}$ & $\begin{array}{l}\text { O } \\
\text { SAEB - } \\
\text { Sistem } \\
\text { a de } \\
\text { Avaliaç } \\
\text { ão da } \\
\text { Educaç } \\
\text { ão } \\
\text { Básica: } \\
\text { potenci } \\
\text { alidade } \\
\text { s, } \\
\text { proble } \\
\text { mas e } \\
\text { desafio } \\
\text { s. }\end{array}$ & $\begin{array}{l}\text { http://www } \\
\text {.educacaoe } \\
\text { pesquisa.fe. } \\
\text { usp.br/wp- } \\
\text { content/upl } \\
\text { oads/2013/ } \\
\text { 09/v.40- } \\
\text { n.1.pdf }\end{array}$ & - & 2014 & $\begin{array}{l}\text { Síntese das sugestões } \\
\text { e recomendações } 1 . \\
\text { Explicitação de um } \\
\text { Sistema Nacional de } \\
\text { Avaliação da } \\
\text { Educação Básica, } \\
\text { com os estudos } \\
\text { específicos alocados } \\
\text { dentro do sistema. } 2 \text {. } \\
\text { Inclusão no } \\
\text { mencionado sistema } \\
\text { de um estudo } \\
\text { longitudinal que } \\
\text { tenha como } \\
\text { população de } \\
\text { referência a } \\
\text { população estudantil } \\
\text { de escolas urbanas. } 3 \text {. } \\
\text { Existência de comitê } \\
\text { multidisciplinar de } \\
\text { especialistas para } \\
\text { cada estudo, com a } \\
\text { missão de oferecer } \\
\text { uma visão de } \\
\text { conjunto que informe } \\
\text { as decisões sobre } \\
\text { "demandas } \\
\text { antagônicas" no } \\
\text { âmbito de cada } \\
\text { estudo. } 3 \text {. } \\
\text { Manutenção e } \\
\text { aprimoramento da } \\
\text { dimensão de } \\
\text { explicação do SAEB. } \\
4 . \text { Aprimoramento } \\
\text { dos aspectos técnicos } \\
\text { ainda problemáticos } \\
\text { no SAEB. } 5 . \\
\text { Incorporação de } \\
\text { novas medidas } \\
\text { relevantes para } \\
\text { professores e gestores } \\
\text { no SAEB. } 6 . \\
\text { Aprimoramento dos } \\
\text { padrões de interação } \\
\text { com estados e } \\
\text { municípios. }\end{array}$ \\
\hline 16 & $\begin{array}{l}\text { PERONI, } \\
\text { Vera } \\
\text { Maria } \\
\text { Vidal; } \\
\text { OLIVEIR } \\
\text { A, Regina } \\
\text { Tereza } \\
\text { Cestari de; }\end{array}$ & $\begin{array}{l}\text { Estado } \\
\text { e } \\
\text { terceiro } \\
\text { setor: } \\
\text { as } \\
\text { novas } \\
\text { regulaç } \\
\text { ôes }\end{array}$ & $\begin{array}{l}\text { https://repo } \\
\text { sitorio.ufm } \\
\text { s.br: } 8443 / \text { js } \\
\text { pui/handle/ } \\
123456789 \\
\text { /557 }\end{array}$ & $\begin{array}{l}\text { Estado; } \\
\text { Público e } \\
\text { privado; } \\
\text { Terceira via; } \\
\text { Terceiro setor; } \\
\text { Gestão da } \\
\text { educação } \\
\text { básica. }\end{array}$ & 2009 & $\begin{array}{l}\text { Ao se discutir as } \\
\text { novas orientações } \\
\text { entre o público e o } \\
\text { privado, neste } \\
\text { período particular do } \\
\text { capitalismo, e as suas } \\
\text { consequências para a } \\
\text { gestão da educação }\end{array}$ \\
\hline
\end{tabular}




\begin{tabular}{|c|c|c|c|c|c|c|}
\hline & $\begin{array}{l}\text { FERNAN } \\
\text { DES, } \\
\text { Maria } \\
\text { Dilnéia } \\
\text { Espíndola. }\end{array}$ & $\begin{array}{l}\text { entre o } \\
\text { público } \\
\text { e o } \\
\text { privado } \\
\text { na } \\
\text { gestão } \\
\text { da } \\
\text { educaç } \\
\text { ão } \\
\text { básica } \\
\text { brasilei } \\
\text { ra. }\end{array}$ & & & & $\begin{array}{l}\text { básica, entende-se } \\
\text { que a gestão } \\
\text { democrática da } \\
\text { educação - processo } \\
\text { ainda em construção } \\
\text {-, em uma conjuntura } \\
\text { de correlação de } \\
\text { forças societárias em } \\
\text { disputa, necessita } \\
\text { voltar, mais uma vez, } \\
\text { ao centro do debate } \\
\text { educacional. }\end{array}$ \\
\hline 17 & $\begin{array}{l}\text { NARDI, } \\
\text { Elton } \\
\text { Luiz; } \\
\text { SCHNEID } \\
\text { ER, } \\
\text { Marilda } \\
\text { Pasqual; } \\
\text { RIOS, } \\
\text { Mônica } \\
\text { Piccione } \\
\text { Gomes. }\end{array}$ & $\begin{array}{l}\text { Qualid } \\
\text { ade na } \\
\text { educaç } \\
\text { ão } \\
\text { básica: } \\
\text { ações e } \\
\text { estratég } \\
\text { ias } \\
\text { dinami } \\
\text { zadoras } \\
\text {. }\end{array}$ & $\begin{array}{l}\text { https://seer. } \\
\text { ufrgs.br/ind } \\
\text { ex.php/edu } \\
\text { cacaoereali } \\
\text { dade/article } \\
\text { /view/4106 } \\
\text { 2/28858 }\end{array}$ & $\begin{array}{l}\text { Qualidade da } \\
\text { Educação } \\
\text { Básica. Ações } \\
\text { e Estratégias. } \\
\text { Índices e } \\
\text { Indicadores } \\
\text { Oficiais. }\end{array}$ & 2014 & $\begin{array}{l}\text { Em um contexto que } \\
\text { informa o reforço da } \\
\text { posição do Ideb como } \\
\text { principal referência } \\
\text { no monitoramento da } \\
\text { qualidade da } \\
\text { educação básica } \\
\text { brasileira, a despeito } \\
\text { da complexidade de } \\
\text { fatores e elementos } \\
\text { que envolvem a } \\
\text { qualidade enquanto } \\
\text { produto histórico e } \\
\text { social que reflete } \\
\text { posicionamentos } \\
\text { políticos e } \\
\text { ideológicos (Barretto, } \\
\text { 2001), a articulação } \\
\text { aqui destacada } \\
\text { representa, sem } \\
\text { dúvida, um desafio a } \\
\text { ser enfrentado. }\end{array}$ \\
\hline 18 & $\begin{array}{l}\text { FACCI, } \\
\text { Marilda } \\
\text { Gonçalves } \\
\text { Dias; } \\
\text { URT, } \\
\text { Sonia da } \\
\text { Cunha; } \\
\text { BARROS, } \\
\text { Ana } \\
\text { Teresa } \\
\text { Fernandes. }\end{array}$ & $\begin{array}{l}\text { Profess } \\
\text { or } \\
\text { readapt } \\
\text { ado: a } \\
\text { precari } \\
\text { zação } \\
\text { do } \\
\text { trabalh } \\
\text { o } \\
\text { docente } \\
\text { e o } \\
\text { adoeci } \\
\text { mento. }\end{array}$ & $\begin{array}{l}\text { https://ww } \\
\text { w.scielo.br/ } \\
\text { scielo.php? } \\
\text { script=sci_ } \\
\text { abstract\&pi } \\
\text { d=S1413- } \\
855720180 \\
00200281 \\
\& 1 n g=\text { en\& } \\
\text { nrm=iso\&tl } \\
\text { ng=pt }\end{array}$ & $\begin{array}{l}\text { Trabalho } \\
\text { docente; } \\
\text { sofrimento; } \\
\text { Psicologia } \\
\text { Histórico- } \\
\text { Cultural. }\end{array}$ & 2018 & $\begin{array}{l}\text { Entendemos que a } \\
\text { pesquisa que } \\
\text { realizamos com os } \\
\text { professores } \\
\text { readaptados teve } \\
\text { algumas limitações, } \\
\text { entre elas o fato de } \\
\text { lidar com aqueles que } \\
\text { já têm um } \\
\text { diagnóstico. Outros } \\
\text { estudos ainda se } \\
\text { fazem necessários, } \\
\text { compreendendo o } \\
\text { adoecimento para } \\
\text { além da esfera } \\
\text { individual, pois } \\
\text { muitas vezes é este o } \\
\text { caminho encontrado } \\
\text { para explicar porque } \\
\text { o professor adoece e } \\
\text { é submetido ao }\end{array}$ \\
\hline
\end{tabular}




\begin{tabular}{|c|c|c|c|c|c|c|}
\hline & & & & & & $\begin{array}{l}\text { processo de } \\
\text { readaptação. }\end{array}$ \\
\hline 19 & $\begin{array}{l}\text { SAMPAIO } \\
\text {, Maria das } \\
\text { Mercês } \\
\text { Ferreira; } \\
\text { MARIN, } \\
\text { Alda } \\
\text { Junqueira. }\end{array}$ & $\begin{array}{l}\text { Precari } \\
\text { zação } \\
\text { do } \\
\text { trabalh } \\
\text { o } \\
\text { docente } \\
\text { e seus } \\
\text { efeitos } \\
\text { sobre } \\
\text { as } \\
\text { práticas } \\
\text { curricul } \\
\text { ares. }\end{array}$ & $\begin{array}{l}\text { http://cev.o } \\
\text { rg.br/biblio } \\
\text { teca/precari } \\
\text { zacao- } \\
\text { trabalho- } \\
\text { docente- } \\
\text { seus- } \\
\text { efeitos- } \\
\text { sobre-as- } \\
\text { praticas- } \\
\text { curriculares } \\
\text { / }\end{array}$ & $\begin{array}{l}\text { Precarização; } \\
\text { Docência; } \\
\text { Currículo. }\end{array}$ & 2004 & $\begin{array}{l}\text { Os dados aqui } \\
\text { expostos indicam a } \\
\text { gravidade da situação } \\
\text { atual de crise e o } \\
\text { delineamento de um } \\
\text { novo modo de } \\
\text { organizar a prática e } \\
\text { o currículo, em que } \\
\text { se vai destituindo o } \\
\text { lugar do } \\
\text { conhecimento e da } \\
\text { reflexão. É evidente o } \\
\text { serviço à ordem } \\
\text { vigente de estudos } \\
\text { que reduzam os } \\
\text { problemas a questões } \\
\text { de gestão e de } \\
\text { ineficiência da } \\
\text { escola, ou a } \\
\text { impropriedades e } \\
\text { irrelevância do } \\
\text { currículo, já que a } \\
\text { relação de } \\
\text { desvalorização e } \\
\text { relativização total do } \\
\text { conhecimento se } \\
\text { articula ao desmonte } \\
\text { da escola pública e } \\
\text { acompanha o } \\
\text { movimento de } \\
\text { desvalorização das } \\
\text { pessoas que usam a } \\
\text { escola e fazem dela } \\
\text { seu posto de trabalho. }\end{array}$ \\
\hline 20 & $\begin{array}{l}\text { CHIRINE } \\
\text { A, Andréia } \\
\text { Melanda; } \\
\text { BRANDA } \\
\text { O, Carlos } \\
\text { da } \\
\text { Fonseca. }\end{array}$ & $\begin{array}{l}\text { O } \\
\text { IDEB } \\
\text { como } \\
\text { política } \\
\text { de } \\
\text { regulaç } \\
\text { ão do } \\
\text { Estado } \\
\text { e } \\
\text { legitim } \\
\text { ação da } \\
\text { qualida } \\
\text { de: em } \\
\text { busca } \\
\text { de } \\
\text { signific } \\
\text { ados }\end{array}$ & $\begin{array}{l}\text { http://revist } \\
\text { as.cesgranri } \\
\text { o.org.br/ind } \\
\text { ex.php/ensa } \\
\text { io/article/vi } \\
\text { ew/741 }\end{array}$ & $\begin{array}{l}\text { Gestão. } \\
\text { Escola } \\
\text { pública. } \\
\text { Qualidade } \\
\text { educacional. } \\
\text { Avaliação } \\
\text { externa. }\end{array}$ & 2015 & $\begin{array}{l}\text { O que o Estado } \\
\text { entende como } \\
\text { qualidade na } \\
\text { educação está } \\
\text { relacionado apenas a } \\
\text { conhecimentos e } \\
\text { habilidades passíveis } \\
\text { de serem mensurados } \\
\text { via testes } \\
\text { padronizados, pois a } \\
\text { política empreendida } \\
\text { pelo Estado, ao } \\
\text { estabelecer o IDEB } \\
\text { como referencial de } \\
\text { qualidade, pautou-se } \\
\text { numa dimensão } \\
\text { generalizada e global } \\
\text { de educação, sem } \\
\text { levar em }\end{array}$ \\
\hline
\end{tabular}




\begin{tabular}{|c|c|c|c|c|c|c|}
\hline & & & & & & $\begin{array}{l}\text { consideração as } \\
\text { peculiaridades de } \\
\text { cada região, de cada } \\
\text { município e de cada } \\
\text { escola, assim como } \\
\text { seus contextos e } \\
\text { especificidades. Uma } \\
\text { das perspectivas para } \\
\text { que isso ocorra } \\
\text { efetivamente é aliar a } \\
\text { avaliação externa à } \\
\text { autoavaliação da } \\
\text { escola. Para finalizar, } \\
\text { consideramos que a } \\
\text { qualidade ainda é o } \\
\text { grande desafio da } \\
\text { educação brasileira, } \\
\text { porém, enquanto não } \\
\text { forem considerados a } \\
\text { clientela e os } \\
\text { contextos próprios } \\
\text { em que cada } \\
\text { "educação" se faz, o } \\
\text { país periga continuar } \\
\text { a formar alunos } \\
\text { capazes de realizar as } \\
\text { provas das avaliações } \\
\text { externas, mas } \\
\text { incapazes de } \\
\text { mobilizar } \\
\text { conhecimentos em } \\
\text { situações reais. }\end{array}$ \\
\hline 21 & $\begin{array}{l}\text { FRANCO, } \\
\text { Ana Maria } \\
\text { Paiva; ME } \\
\text { NEZES } \\
\text { FILHO, } \\
\text { Naércio. }\end{array}$ & $\begin{array}{l}\text { Uma } \\
\text { análise } \\
\text { das } \\
\text { classifi } \\
\text { cações } \\
\text { das } \\
\text { escolas } \\
\text { brasilei } \\
\text { ras com } \\
\text { dados } \\
\text { do } \\
\text { SAEB. }\end{array}$ & $\begin{array}{l}\text { https://ww } \\
\text { w.scielo.br/ } \\
\text { pdf/ee/v42 } \\
\text { n2/02.pdf }\end{array}$ & $\begin{array}{l}\text { educação, } \\
\text { desempenho, } \\
\text { classificação, } \\
\text { incentivos }\end{array}$ & 2012 & $\begin{array}{l}\text { A elevada } \\
\text { estratificação do } \\
\text { sistema, por um lado, } \\
\text { e o processo de } \\
\text { reversão para a média } \\
\text { que tende a ocorrer } \\
\text { nos resultados de um } \\
\text { momento no tempo } \\
\text { para o outro, geram } \\
\text { ruídos nas medidas } \\
\text { de desempenho } \\
\text { utilizadas para a } \\
\text { construção de } \\
\text { rankings, de forma } \\
\text { que estes possam } \\
\text { apresentar resultados } \\
\text { influenciados } \\
\text { principalmente pelo } \\
\text { status } \\
\text { socioeconômico dos } \\
\text { alunos ou uma } \\
\text { volatilidade grande } \\
\text { de um período de }\end{array}$ \\
\hline
\end{tabular}




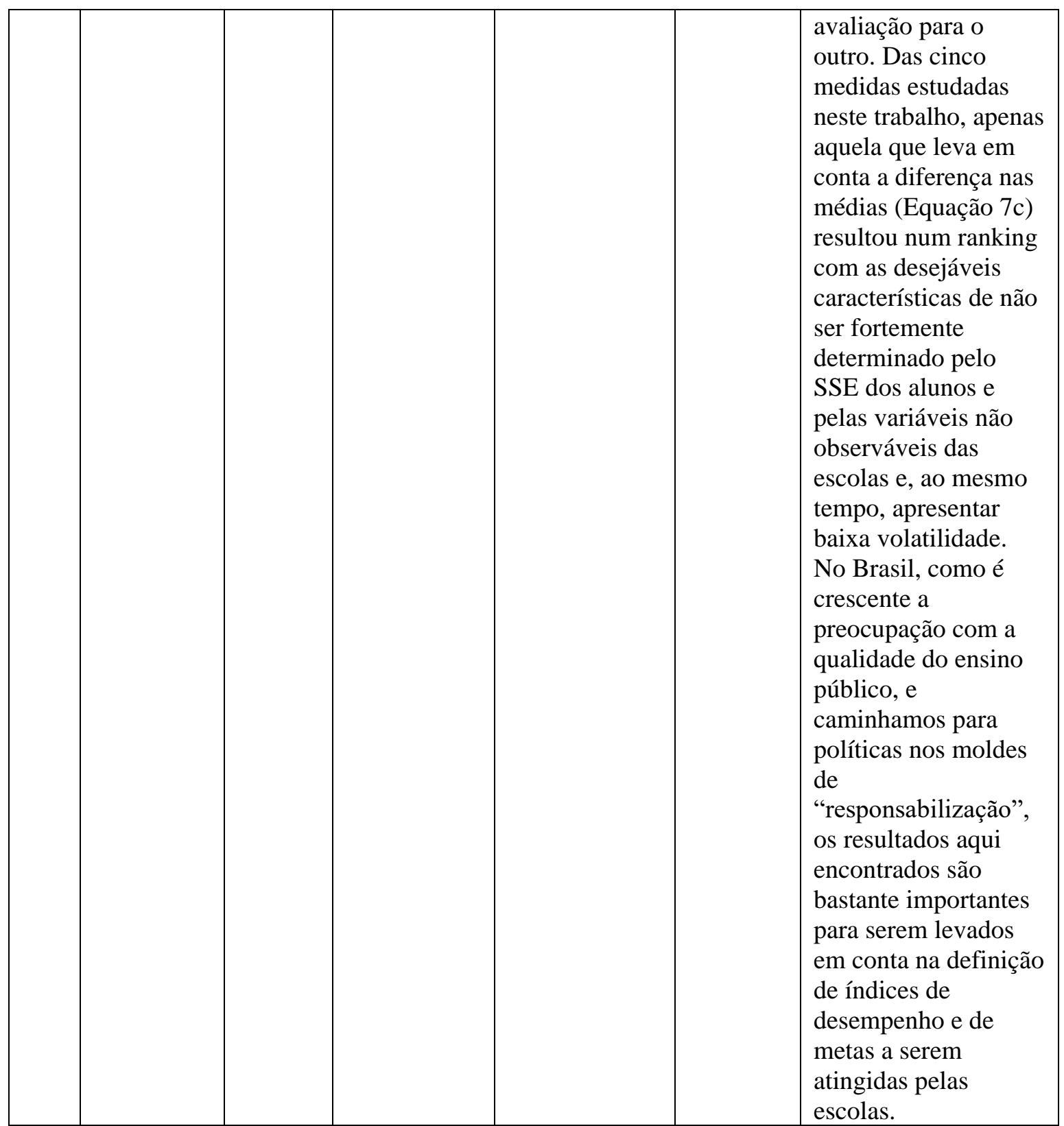

FONTE: Autoria própria.

Dos 21 artigos selecionados os seguintes autores: Garay (2011), Taylor e Fayol (2004), Chiavenato (2004), Machado (2000), Paro (1986), Lück (2009), Gonçalves (2012) e Veiga (2011), integraram os temas relacionados com os conceitos educacionais de gestão escolar; Darling-Hammond e Ascher (1991), Gentili (1997), Semeghini (2001), Freitas (2004),
Araújo (2006) e Azevedo (2011), trataram sobre a gestão escolar contextualizando a qualidade no ensino da educação básica pública no Brasil; Gonçalves (2012), Saviani (2007), Portela (2008), Sousa (2008), abordaram a avaliação do SAEB e IDEB para a qualidade do ensino; e Martins e Eidt (2010), Paro (1986), Silva (1986), Silva Júnior (2002), apresentam as principais dificuldades no trabalho 
educacional básico e a participação da gestão democrática.

\section{DISCUSSÃO}

A gestão escolar é composta de um dos campos de atuação profissional na educação destinada a desempenhar: planejamento, organização, autoridade, a orientação, coordenação, monitoramento e a avaliação dos procedimentos precisos na efetividade de ações educacionais direcionadas para o incentivo da aprendizagem e formação dos estudantes. Segundo Garay (2011), gestão é o processo de dirigir a organização e, a partir daí, tomar decisões considerando os recursos disponíveis e as demandas disponíveis no ambiente escolar. Já Taylor e Fayol (ANO) numa abordagem clássica apontam que "define o ato de administrar como: prever, organizar, comandar, coordenar e controlar. Chiavenato (2004), por conseguinte, a tais definições temos que, "o gestor escolar é responsável pela administração utilizandose de concepções e ferramentas administrativas, visando o alcance de objetivos e metas pré-estabelecidas'.

No campo empírico, diagnosticouse que a gestão, como organização do trabalho na escola (MACHADO, 2000) e/ou como utilização racional de recursos para se atingir fins determinados (PARO, 1986), vem se constituindo para o alcance de resultados/índices, lançando mão de estratégias, inclusive, não coerentes com a práxis pedagógica.

A gestão está inserida em todas as instituições e empresas, sejam elas públicas ou particulares, sendo fundamental e precisa no setor de educação. A gestão escolar engloba as incumbências que as unidades escolares possuem, tais como: elaborar e executar a proposta pedagógica, administrar o pessoal e os recursos materiais e financeiros. Conforme a Lei 9.394/96 (BRASIL, 1996. ${ }^{a}$ ) da Lei de Diretrizes e Bases da Educação Nacional (LDBEN), que as escolas possuem autonomia para atender as particularidades regionais e locais dos seus alunos, no entanto, precisam respeitar as normas comuns dos sistemas de ensino.

No Brasil, a gestão educacional que é determinada por orientações previstas na Lei 9.394/96 (BRASIL, 1996. ${ }^{\mathrm{a}}$ ), onde a mesma menciona o modelo democrático e participativo da administração escolar, este modelo caracteriza a gestão educacional. $\mathrm{O}$ processo de gestão nas instituições de ensino precisa ser global, sendo de responsabilidade de toda a comunidade escolar. Participam deste processo o diretor de escola, o coordenador pedagógico, o supervisor de ensino, os professores e todos 
Rev. Científica Evidência, Maceió, v. 3, n.1, p. 29-61, jul/set, 2020

os demais funcionários, além da família que tem um papel importante e fundamental neste processo.

De acordo com Lück (2007), a gestão escolar evidencia-se na literatura a partir dos anos 90, sendo reconhecida como base fundamental para a organização significativa e estabelecimento dos processos educacionais e mobilização de pessoas voltadas para o desenvolvimento e melhoria da qualidade de ensino que oferecem. A gestão escolar tem que ser construída coletivamente, não pode ser fragmentada e sim participativa e democrática. Assim Lück (2009), aponta que, a gestão escolar necessita de uma constante adaptabilidade quanto ao contexto inserido atribuindo uma flexibilidade para aplicações de ações efetivas aos gestores. Na educação básica o gestor escolar desempenha um papel significativo uma vez que se desenvolve em todos os âmbitos da escola, inclusive e fundamentalmente, na sala de aula.

Portanto, a rotina da gestão educacional demanda atenção a partir dos primeiros anos formadores dos educandos, utilizando-se da adequação da realidade da instituição de ensino. Conforme aponta Gonçalves (2012): “A educação escolar possui função de promover apropriação de saberes, procedimentos, atitudes e valores por parte dos alunos, pela ação mediadora do ensino, e pela gestão e organização da escola". Sendo assim, Veiga (2011) conclui que para o cumprimento deste objetivo, "é necessário convencer os professores, funcionários e equipe escolar a trabalhar mais, proporcionando situações que lhes permitam aprender e a realizar o fazer pedagógico de forma coerente.”

Portanto, é importante discorrer sobre esses conceitos permeiam os atos do gestor educacional de modo a otimizar o seu trabalho pedagógico.

\section{A gestão escolar sobre o contexto da qualidade do ensino básico público brasileiro}

Sabendo do conceito bem como das ações do gestor educacional, um tema identificado na revisão foi a importância da gestão escolar para o desenvolvimento da educação pública no contexto do ensino básico em séries iniciais.

Na Constituição Federal de 1988 (BRASIL, 1988), avaliação educacional é tratada de forma associada à qualidade da educação. No art. 206, a "garantia de padrão de qualidade" figura como um dos princípios basilares do ensino. No art. 209, a avaliação da qualidade pelo poder público aparece como condição do ensino livre à iniciativa privada. Todavia ao tratar do Plano Nacional de Educação, o art.214 indica como um dos resultados pretendidos a "melhoria da qualidade do ensino" (BRASIL, 1988). 
O novo desafio dos gestores contemporâneos não é apenas conhecer o processo histórico educacional, mas ter competências e habilidades de analisar as mazelas sociais e, se propor a agir como sujeito da história, em que a sala de aula se constitui em um espaço interativo de debates e discussões dialógicas em prol da formação, pois ao se sentirem sujeitos do processo professor e aluno terão atitudes e desempenhos diferenciados na construção e busca incessante do conhecimento.

A partir da necessidade de atender a demanda das expectativas de pais, alunos e sociedade a labuta da educação é constante. Decerto, que identificar a implantação das melhores estratégias e identificar as suas condições de mudanças atribui a melhoria continuada nos processos de ensino aprendizagem do alunado.

Assim, com o crescente interesse pela avaliação da qualidade nos sistemas educacionais foram instituídos índices de indicadores de desenvolvimento educacionais (IDEB), planos sistemáticos avaliativos de educação básica (SAEB), dentre outros. Segundo Ferrer (1996), a pressão das mudanças contextuais sobre os sistemas de ensino: mudanças nos modos de administração e controle desses sistemas; demanda social de informação e prestação de contas; novo modelo de gestão educacional, motivaram esse aumento de interesse. A partir dessa compreensão,
Darling-Hammond e Ascher (1991) salientam que entre as dimensões de fatores na qualidade da educação deve se expressar as relações de: a) validade - entre os objetivos educacionais e os resultados escolares, não se reduzindo a médias ou similares; b) credibilidade - tendo em vista, elementos que possam ser confiáveis em termos do universo escolar; c) incorruptibilidade - ou melhor, fatores que tenham menor margem de distorção; d) comparabilidade - ou seja, aspectos que permitam avaliar as condições da escola ao longo do tempo.

A qualidade da educação, portanto, não circunscreve as médias, em um dado momento, a um aspecto, mas configura-se como processo complexo e dinâmico, margeado por um conjunto de valores como credibilidade, comparabilidade, entre outros. Ratifica-se, portanto, que qualidade da educação é um conceito polissêmico e multifatorial, pois a definição e a compreensão teórico-conceitual e a análise da situação escolar não pode deixar de considerar as dimensões extraescolares que permeiam tal temática. Gentili (1997, p. 115) lembra que: "O discurso da qualidade referente ao campo educacional começou a desenvolver-se em fins da década de 80 como contraface do discurso da democratização".

Nesse sentido, Semeghini (2011, p.56), aponta que “é inegável que os 
Rev. Científica Evidência, Maceió, v. 3, n.1, p. 29-61, jul/set, 2020

indicadores de qualidade do ensino público, quando consultados, ainda reiteram uma situação que está muito aquém do razoável".

Com o propósito avaliativo, caracterizam-se os "grandes traços ou características referentes aos aspectos institucionais sobre os quais se emite juízo de valor e que, em seu conjunto, expressam a totalidade da instituição", por outro lado o indicador diz respeito a "algum aspecto ou característica da realidade que se pretende avaliar" (Brasil, 2005a, p. 37). Na esfera avaliativa, é cada vez mais necessário atribuir significados às novas práticas adotadas; análises pautadas em diversas interpretações paralelas conduzem a uma ampla profusão de significações, pois não há uma linguagem uniforme para tratar das práticas avaliativas.

Assim Freitas (2004, p.149) afirma que “(...) o conceito de avaliação que emergiu privilegiou a avaliação externa em todos os níveis de ensino, sob a lógica da competitividade entre as organizações ou entre os professores, em que a qualidade era produto da própria competição pela construção de uma coleção de indicadores legitimados socialmente pelos atores".

Diante disso, para desenvolver a qualidade da educação no ensino básico, deve-se atrelar os avaliadores de índices e indicadores a implementação de um concreto plano pedagógico sistemático associado a políticas educacionais. O estudo de Araújo (2006) mostra que, no Brasil, as crianças que iniciam seus estudos já na préescola têm, em média, um desempenho escolar melhor.

As consequências da implementação de políticas educacionais, presentes nas diversas gerações, sobre a qualidade da educação nos apresenta uma realidade subjetiva, porquanto mesmo com resultados relativamente positivos ainda há muito o que melhorar em sua abrangência ao nível nacional. Decerto, não resta dúvida de que a questão da qualidade da educação ainda é mediana em escolas públicas ficando bem aquém de habilidades em matemática e em leitura, consideradas como fundamentais ao término do primeiro segmento do ensino fundamental.

É certo que pensar a qualidade implica considerar o uso de medidas comparativas que permitam distinguir entre o que seria uma boa ou uma má qualidade, posto que ela é mais facilmente percebida pela falta de, ou seja, pelos atributos que não atendem aos padrões considerados adequados, do que pela presença deles.

Em vista disso Azevedo (2011) afirma que a qualidade e quantidade constituem elementos inseparáveis, embora esses não possam e não devam ser confundidos. Assim, no âmbito das recentes políticas educacionais brasileiras, temos evidenciado a tendência ao 
Rev. Científica Evidência, Maceió, v. 3, n.1, p. 29-61, jul/set, 2020

desenvolvimento de ações e programas que reforçam a tradução da qualidade através de atributos passíveis de serem medidos.

E diante desse desafio de equacionar a qualidade do ensino básico brasileiro, será abordado a importância das avaliações do SAEB e IDEB para a qualidade na educação.

\section{A avaliação do SAEB e IDEB para qualidade do ensino}

A despeito dos diferentes posicionamentos de estudiosos da área sobre a potencialidade dos indicadores para os propósitos de qualidade almejados (Saviani, 2007; Portela, 2008; Sousa, 2008), parece haver um razoável consenso de que a criação de um instrumento de aferição do desenvolvimento da educação básica representa avanço significativo nas condições de acompanhamento e monitoramento da situação educacional brasileira. Uma vez que, a instituição escolar tem por função proporcionar uma excelência no ensino básico, os instrumentos avaliativos são de fundamental importância para o estabelecimento de parâmetros confiáveis.

E nesse contexto, que é criado o Índice de Desenvolvimento da Educação Básica (IDEB), que vem a ser um indicador do Ministério da Educação (MEC), elaborado pelo Instituto Nacional de Estudos e Pesquisas Educacionais “Anísio
Teixeira" (INEP), reunindo dados do Sistema de Avaliação da Educação Básica (SAEB) e da Prova Brasil. A combinação desses dados gera um parâmetro balizador de metas a serem atingidas, com o propósito de monitorar e avaliar o sistema educacional do país, assim como assegurar a melhoria na qualidade da educação.

O IDEB como parte integrante do Plano de Desenvolvimento da Educação (PDE) segue o compromisso de alcançar metas propostas no programa, a fim de alcançar a qualidade educacional, bem como a mobilização social.

Ademais o Sistema de Avaliação da Educação Básica (SAEB) é um conjunto de avaliações que permite ao Inep realizar uma diagnose da educação básica brasileira, qualificando desempenho dos discentes. Assim, aplicados a cada dois anos na rede pública e em uma amostra da rede particular, o Saeb apresenta os níveis de aprendizagem dos aferidos, esclarecendo os resultados obtidos a partir de uma série de informações em sua conjuntura.

O Saeb permite que as instituições municipais e estaduais de ensino avaliem a qualidade da educação oferecida aos estudantes, sendo um indicativo do resultado avaliativo do ensino brasileiro, oferecendo subvenção e o aprimoramento de políticas educacionais com base em evidências. O desempenho dos estudantes, nos testes propostos também compõem do 
Rev. Científica Evidência, Maceió, v. 3, n.1, p. 29-61, jul/set, 2020

Índice de Desenvolvimento da Educação Básica (IDEB). Os programas citados contemplam desde a educação infantil como o ensino fundamental e o ensino médio.

Para Souza (1997, p. 264) “[...] a educação precisa alcançar qualidade capaz de responder às demandas decorrentes das transformações globais nas estruturas produtivas e do desenvolvimento tecnológico".

Há de se ressaltar ainda que entendemos que a avaliação se constitui em uma condição necessária à melhoria da qualidade de ensino no país, principalmente na escola pública. No Brasil, como é crescente a preocupação com a qualidade do em sino público, e caminhamos para políticas nos moldes de "responsabilização", os resultados encontrados são importantes para serem levados em conta na definição de índices de desempenho e de metas a serem atingidas pelas escolas.

No entanto, no que tange as questões de qualidade, a busca e melhoria devem emergir do núcleo da própria escola e dos gestores escolares que dentro desta atuam e frequentam, exigindo do Estado, enquanto propositor e regulador de políticas, as condições acima referidas para que haja a efetiva qualificação das escolas e dos sistemas de ensino.

\section{As dificuldades no trabalho educacional}

\section{básico e a participação da gestão democrática.}

A avaliação do ensino constitui em uma condição necessária à melhoria da qualidade de ensino no país e também permite identificar as principais dificuldades encontradas para buscar as melhorias do ensino. E integra-se aqui, a necessidade da atenção por parte do gestor educacional em fomentar meios estratégicos para melhoria, incluindo a melhoria do trabalho dos profissionais envolvendo uma gestão democrática de forma participativa.

A relação entre o educador $\mathrm{e}$ a precarização de seu trabalho é um fenômeno discutido em muitas esferas de nossa sociedade atualmente. Isso porque $\mathrm{o}$ docente desenvolve um trabalho contínuo mesmo em condições não favoráveis ao desenvolvimento das ações fundamentais para formação inicial de seus educandos. A falta de insumos básicos para realização dos trabalhos ainda é uma realidade vivenciada por muitos profissionais da área e está intrinsicamente relacionada com a qualidade do trabalho dos docentes.

Tais aspectos também são relatados pelos próprios gestores escolares que citam em diversas pesquisas que as condições de infraestrutura física e pedagógica das escolas, tais como falta de suporte técnico pedagógico; infraestrutura física de má qualidade; salas superlotadas, local com 
muito ruído; falta de material pedagógico; que caracterizam a dificuldade na obtenção da qualidade de ensino exigida.

Assim, à falta de investimento necessária por parte dos governantes na educação, principalmente no que tange as regiões que apresentam uma população de baixo potencial aquisitivo, emprega uma série de retardamentos quanto a evolução educacional dos estudantes a partir das séries iniciais de formação. Nesse sentido, Martins e Eidt (2010) citam que a atividade dos profissionais tem como função produzir e reproduzir as condições necessárias para inserção do homem na sociedade.

A falta das condições para realização dessas atividades para com o educando e a precarização na prestação do serviço contribui para uma relação limitada do trabalho por parte dos envolvidos, podendo gerar, inclusive, desmotivação por parte do gestor escolar, docente ou até mesmo por parte dos discentes. Diante disso, o gestor educacional e sua equipe deve atinar suas ações de forma estratégica.

Entretanto, em 15 de março de 2007, é divulgada uma política de governo denominada Plano de Desenvolvimento da Educação - PDE - que, pela primeira vez no Brasil, envolve em um mesmo eixo diretor a educação básica, superior, profissional e continuada.

De acordo com Marchelli (2010):
O PDE surge num momento em que a educação brasileira, sob o impacto da divulgação da série histórica do Saeb do período 19952005, é considerada uma das piores do mundo, ressaltando a necessidade de que uma ação conjunta das esferas municipais, estaduais e federal fosse empreendida para enfrentar os problemas. (Marchelli, p.578)

Esses elementos permitiram que o grupo considerasse fundamental atrelar à discussão da administração/gestão escolar as questões relacionadas à qualidade do ensino, o que é bastante coerente com as discussões teóricas da área que concebem a administração/gestão como mediação para se atingir fins (PARO,1986).

O foco da visão sistêmica pretendida pelo PDE para a educação básica contempla a melhoria da qualidade por meio do aumento nos investimentos e aperfeiçoamento da gestão de recursos pelos agentes públicos responsáveis. Entre as medidas adotadas, está a criação do Índice de Desenvolvimento da Educação Básica - Ideb -, decorrente de uma nova geração de indicadores para avaliar a qualidade de ensino no país. De acordo com Silva Júnior (2002) nesse caso, a aptidão da gestão como "democrática" e/ou "participativa" tem um desdobramento que sobrepõe esses adjetivos ao qualificativo "pública”. Isso porque para o autor a "gestão pública" requer a posição de 
práticas de administração privada na administração pública.

Nesse emaranhado de qualificações, encontram-se até mesmo abordagens que apresentam a "gestão compartilhada" como se fosse o mesmo que "gestão democrática", ou a manifestação maior desta. O que nos traz a deliberação de que para uma gestão eficaz no desenlace dessa problemática, o conceito de que a administração e solução do exposto requer uma eficiente avaliação das medidas a serem adotadas a fim de melhorar o suporte para os profissionais efetivando a excelência pedagógica no ensino básico.

Assim, a gestão educacional nacional é baseada na organização dos sistemas de ensino federal, estadual e municipal e das incumbências desses sistemas; das várias formas de articulação entre as instâncias que determinam as normas, executam e deliberam no setor educacional; e da oferta da educação pelo setor público e privado. Diferente da gestão educacional, a gestão escolar, trata das incumbências que os estabelecimentos de ensino possuem, respeitando as normas comuns dos sistemas de ensino.

Cada escola deve elaborar e executar sua proposta pedagógica; administrar seu pessoal e seus recursos materiais e financeiros; cuidar do ensinoaprendizado do aluno, proporcionando meios para a sua recuperação; e articular-se com as famílias e a comunidade, proporcionando um processo de integração entre as partes.

Portanto, salienta-se que cada sistema tem um papel a desempenhar no contexto educacional do País. No que diz respeito a educação básica, cabe aos Estados, Distrito Federal e Municípios ofertá-la, por sua vez, o ensino médio é um dever dos Estados e do Distrito Federal e a educação infantil dos Municípios.

\section{Precarização no trabalho educacional básico}

A precarização do trabalho dos profissionais educadores caracteriza uma das dificuldades na obtenção da qualidade de ensino exigida, e nessa revisão além desse fator, outras variantes acerca da problemática foram identificadas.

Os professores, considerados como trabalhadores, padecem com a precarização do trabalho. Tumolo e Fontana (2008) afirmam que esses profissionais, tais como outras categorias, vivenciam o processo de proletarização de suas condições de trabalho, configurado como rebaixamento salarial, desqualificação da atividade realizada, desvalorização social da profissão, perda de controle do processo de trabalho. Logo a precarização, no caso da atividade do docente, incide juntamente com as reformas educacionais. Assunção e 
Oliveira (2009) afirmam que essas reformas propostas no Brasil, a partir de 1990, ocorrem coerentes com as reformas do Estado na forma de gestão pública, que busca uma descentralização administrativa e financeira, repassando obrigações e responsabilidades para as próprias escolas, trazendo como consequência: “... financiamento per capita, a regularidade e ampliação dos exames nacionais de avaliação, maior flexibilidade curricular, a avaliação institucional e a participação da comunidade na gestão escolar" (ASSUNÇÃO; OLIVEIRA, 2009, p. 351). Pois, a eficácia na produtividade e excelência transpõem as relações trabalhistas. O professor está cada vez mais abatido pela intensificação do trabalho, ficando susceptível ao adoecimento, uma vez que tem que extrapolar os seus limites. Portanto, foi observado durante essa pesquisa a ocorrência de professore que adoeceram em função do excesso de trabalho, da sobrecarga de trabalho, das cobranças e da aflição em conseguir cumprir as tarefas dentro dos prazos estabelecidos.

Em vista disso, os professores da educação básica ainda são avaliados, constantemente, pelos índices de desempenho dos educandos, estes medidos pelos sistemas de avaliação como por exemplo, pelo Índice de Desenvolvimento da Educação Básica (IDEB) - que avalia a afluência escolar e as médias de desempenho nas avaliações, que dá um ranking das melhores escolas. Desta maneira, os próprios docentes se autorregulam perenemente. Assim, as reformas educacionais e os vários sistemas avaliativos causam danos à saúde psicológica dos professores e gestores. Ainda nesse seguimento da precarização do trabalho dos professores, Sampaio e Marin (2004), igualmente, apresentam alguns elementos que estão presentes na atividade destes profissionais.

Diante disso, no tocante à necessidade de escolaridade, a precarização se dá principalmente no caso de professores inexperientes que sem a devida troca de experiência com os mais antigos se veem por vezes desmotivados, e no caso daqueles que têm experiência em trabalhar conteúdos diversificados ao mesmo tempo, desgastam-se com os anos seguidos. Outro ponto de precarização refere-se às baixas remuneração recebida. Visto que, existem inúmeros paradigmas que causam a precarização, desde a relação às condições de trabalho: carga horária de trabalho e de ensino, tamanho das turmas e razão entre professor/alunos, rotatividade/itinerância dos professores pelas escolas e as questões sobre carreira no magistério são os fatores mais relativos a causa e consequência desta problemática, que se arrasta com o passar dos anos com expectativa de solução, 
porém sempre sendo pauta de debates e embates frequentes.

Abordar as questões relacionadas a falta de coordenação da educação básica no Brasil e da precarização advinda da mesma, não é nada trivial, isso ocorre tanto pela diversidade de tipo de provedores (públicos, privados e não governamentais), quanto pela diversidade de funções realizadas pelos diferentes níveis de governo. Ademais, os municípios são os principais responsáveis pela oferta de educação infantil (de zero a cinco anos); pois respondem pela oferta conjunta de Ensino Fundamental do primeiro ao nono ano (de seis a catorze anos); e os estados são os principais responsáveis pela oferta de Ensino Médio. Sendo que a União, por sua vez, desenvolve papel supletivo em relação a todos os níveis de educação básica cumprindo importante serventia na coordenação de políticas e na avaliação do sistema educacional.

Dessa forma, a mesma ainda é responsável pela regulação, supervisão e pelo financiamento federal de ensino superior que inclui as instituições próprias e o sistema privado. Diante do exposto, uma hipótese bastante plausível é que as questões de organização estejam no cerne dos problemas de implementação das políticas educacionais no Brasil, apesar de serem discutidas de modo comedido. As políticas educacionais são por definição complexas em termos de coordenação dessa organização, pois envolve um ajuntamento muito diversificado de instrumentos, programas e atores. Assim, no Brasil ainda existe um arcabouço legal e instrumentos operacionais relacionados à cooperação para as áreas de financiamento, desenvolvimento escolar, avaliação educacional e de serviços de apoio, como merenda, transporte, livro didático entre outros.

Não obstante, a temática do currículo escolar foi regulada no âmbito das regras relacionadas à Base Nacional Comum para o Ensino Fundamental. No entanto, cabe observar que a presença de estratégias formais de colaboração não necessariamente elimina as constantes ocorrências de dificuldades de organização em áreas já - supostamente - reguladas.

Dessa forma, outro aspecto significativo é que o papel dos governos estaduais não é, em geral, claramente especificado no âmbito das estratégias de coletividade. A não ser no caso do financiamento, que detalha claramente uma regra relacionada ao papel de estados e municípios, nos demais casos, estados e municípios não dispõem de regras universais relacionadas à cooperação mesmo tendo que oferecer de modo compartilhado o Ensino Básico. Quando porventura existem, tais formatos de cooperação entre estados e municípios são estabelecidos através de convênios que 
podem ser firmados ou não, e que podem variar substancialmente caso a caso (CASTRO, 2015; GOMES, 2008).

Outrossim, as diretrizes nacionais para a carreira do magistério, aprovadas em 2010 pelo Conselho Nacional de Educação (CNE) e que dependem de regulamentação federal, também se esbarram com a autonomia local e muitas vezes não se harmonizam às condições de funcionamento dos governos municipais. Sendo este tema fonte de conflito contínuo na organização das carreiras dos profissionais de educação, que não raro trabalham em escolas municipais e estaduais de um mesmo município com carreiras e salários diferentes. Para circunscrever o problema, o que tentaremos notar é até que ponto a permanência ou

\section{CONCLUSÃO}

A educação de qualidade é uma garantia constitucional, no entanto, a realidade vivenciada nacionalmente por educandos está longe de ser consideravelmente aprazível. O que se observa no âmbito da educação básica, é que os gestores têm um desafio constante quanto a adoção de estratégias viabilizando e driblando assim a ineficiência do suporte público na educação. No que tange a meta de uma educação de qualidade, segundo pode ser visto nessa revisão, a educação está migração de estudantes do ensino básico e fundamental entre redes de ensino impacta ou não as variáveis educacionais de desempenho escolar.

Nesse sentido, estaremos assumindo a priori que a permanência em uma mesma rede de ensino (estadual ou municipal) aumenta a probabilidade de maior presença de coordenação, enquanto a migração entre redes de ensino reduz a probabilidade de organização. Todavia, na prática, isso apresenta que a gestão administrativa e pedagógica da educação funciona de modo limitado e faltam mecanismos efetivos de coordenação entre os níveis de governo. Sem dúvida, esse parece ser uma temática de extrema relevância para as políticas de ensino básico no futuro próximo.

de certa forma sendo negligenciada ao povo de maneira plena, o que reflete no fracasso educacional de parte significante da população.

Fracasso que é exposto através de um déficit substancial na aprendizagem dos alunos em suas séries iniciais. Notadamente, os gestores escolares têm papel importante para solução dessa problemática, desde que, possuam o respaldo necessário por parte dos agentes responsáveis por políticas públicas no que concerne ao ensino de qualidade. Logo, mesmo com os índices avaliadores de 
ensino postos, a má qualidade do ensino principalmente, no que versa sobre a educação básica ainda prepondera e elenca a precariedade na efetividade de ações evolutivas no tocante ao aprendizado absorvido por parte dos educandos.

Portanto, tendo em vista os argumentos aqui apresentados fica claro que sem a dicotomia de intervenções sejam elas por parte dos gestores públicos e/ou

\section{REFERENCIAS}

DOURADO, L. F. Gestão da Educação

Escolar. Brasil. Ministério da Educação. Série. CDU 37.014.2 $3^{\mathrm{a}}$ edição atualizada/revisada - 2008.

Disponível em: <http://portal.mec.gov.br/index.php?op tion=com_docman\&view=download \&alias =585-gestao-da-educacao-

escolar\&Itemid=30192> Acesso em: 09 de jun. de 2020 .

\section{OLIVEIRA, Emanuelle. Gestão}

Educacional e Gestão Escolar

Disponível em:<

https://www.infoescola.com/educacao/gest ao-educacional-e-gestao-escolar/> Acesso em: 14 de Mai. De 2020.

ASSUNÇÃO, A. A.; Oliveira, D. (2009). A. Intensificação do trabalho e saúde dos professores. Educação e Sociedade, 30(107), 349-372.

TUMOLO, P. S.; Fontana, K. B. (2008). Trabalho docente e capitalismo: um estudo crítico da produção acadêmica da década de 1990. Educação e Sociedade, 29(102), 159-180.

GOMES, S. C. (2008), Fatores explicativos das diferentes estratégias de municipalização do Ensino Fundamental gestores escolares a excelência no ensino básico não será alcançada. Por fim, salientase que a educação seja ela básica, fundamental ou o ensino médio é um direito de todos, garantidos constitucionalmente e o emprego de políticas públicas eficazes é dever do estado, de modo a formar indivíduos aptos a exercer sua cidadania gozando do convívio social pleno.

\section{nos governos subnacionais do Brasil} (1997-2000). Tese de Doutorado (Ciência Política). São Paulo: USP.

CASTRO, M. H. G. (2015), "Papel dos estados e municípios na implementação das políticas de educação (Brasil)". In: S. Schwartzman (ed.), Education in South América. Londres: Bloomsbury Academic, 2015.

BRASIL. Lei de Diretrizes e Bases da Educação Nacional, n. 9.394, de 20 de dezembro de 1996. Disponível em: http://portal.mec.gov.br. Acesso em: 12 de Mar. de 2020.

VIEIRA, S. L. Educação e gestão: extraindo significados da base legal. In: Ceará. SEDUC. Nos paradigmas de gestão escolar. Fortaleza: edições SEDUC, 2005.

MACHADO, C. Avaliação externa e escolas públicas: elementos de gestão escolar democrática. Estudos em Avaliação Educacional, 2016, Vol.27 (64), pp.218-240 Disponível em: <http://publicacoes.fcc.org.br/ojs/index.ph p/eae/article/view/3485/3161> Acesso em: 15 de Mai. de 2020.

TORRES, H. G.; CAMELO, R.; CASTRO, M. H. G. Dificuldades de Coordenação e Políticas Educacionais no Brasil: O Caso 
do Ensino Fundamental. Dados, Rio de Janeiro , v. 62, n. 4, e20170226, 2019 - Available from $<$ http://www.scielo.br/scielo.php?script=sc i_arttext\&pid=S0011-

52582019000400200\&lng=en\&nrm=iso $>$. Epub Nov 14, 2019. https://doi.org/10.1590/0011525820 19190. Acesso em: 14 de Mai. de 2020.

PASCHOALINO, J. B. Q. Gestão Escolar na Educação Básica: construções e estratégias frente aos desafios profissionais. Educ. Real., Porto Alegre, v. 43, n. 4, p. 1301-1320, out. 2018.

Disponível em:

$<$ http://www.scielo.br/scielo.php?script=sc i_arttext\&pid=S2175-

62362018000401301\&lng=pt\&nrm=iso $>$. https://doi.org/10.1590/2175-623684867.

Acesso em: 14 de Mai. de 2020.

ABDIAN, G. Z.; NASCIMENTO, P. H. C.; SILVA, N. D. B. DESAFIOS TEÓRICO-METODOLÓGICOS PARA AS PESQUISAS EM ADMINISTRAÇÃO/GESTÃO EDUCACIONAL/ESCOLAR. Educ. Soc.,

Campinas, v. 37, n. 135, p. 465-480, June 2016. Available from $<$ http://www.scielo.br/scielo.php?script=sc i_arttext\&pid=S0101$73302016000200465 \& \operatorname{lng}=e n \& n r m=i s o>$. http://dx.doi.org/10.1590/ES010173302016154123. Acesso em: 14 de Mai. de 2020.

SILVA, C. E. (1). Gestão escolar e IDEB: propostas e suas relações para $o$ crescimento do índice de desenvolvimento da Educação Básica dos Anos Finais do Ensino Fundamental nas Escolas Municipais de Paragominas/PABrasil. Revista Internacional De Apoyo a La inclusión, Logopedia, Sociedad Y Multiculturalidad, 4(2). https://doi.org/10.17561/riai.v4.n2.3

DA COSTA, R. V. (2020). Gestão

Democrática: função administrativa pedagógica e a atuação financeira dos gestores nas escolas de Sinop/MT-

Brasil. Revista Internacional De Apoyo a La inclusión, Logopedia, Sociedad Y Multiculturalidad, 6(1), 1-11. https://doi.org/10.17561/riai.v6.n1.01

FREITAS, D. N. T.. Avaliação e gestão democrática na regulação da educação básica brasileira: uma relação a avaliar. Educ. Soc., Campinas , v. 28, n. 99, p. 501-521, Aug. 2007 .Available from

$<$ http://www.scielo.br/scielo.php?script=sc i_arttext\&pid=S0101-

73302007000200011\&lng=en\&nrm=iso>. https://doi.org/10.1590/S010173302007000200011.

Acesso em: 14 Mai. de 2020.

FRANCO, C.; ALVES, F. Bonamino, A. Qualidade do ensino fundamental: políticas, suas possibilidades, seus limites. Educ. Soc.

Campinas, v. 28, n. 100, p. 989-1014, outubro de 2007. Disponível em $<$ http://www.scielo.br/scielo.php?script=sc i_arttext\&pid=S010173302007000300017\&lng=en\&nrm=iso > http://dx.doi.org/10.1590/S010173302007000300017.

Acesso em: 14 de Mai. de 2020.

NARDI, Elton Luiz; SCHNEIDER, Marilda Pasqual; RIOS, Mônica Piccione Gomes. Qualidade na educação básica: ações e estratégias dinamizadoras. Educ. Real., Porto Alegre, v. 39, n. 2, p. 359390, June 2014. Available from $<$ http://www.scielo.br/scielo.php?script=sc i_arttext\&pid=S217562362014000200003\&lng=en\&nrm=iso>. access

on 14 May 2020. https://doi.org/10.1590 /S2175-62362014000200003.

SAMPAIO, M. M. F.; Marin, A. J. (2004). Precarização do trabalho docente e seus efeitos sobre as práticas curriculares. 
Educação e Sociedade, 25 (89), 12031225.

DOURADO, L. F.; OLIVEIRA, J. F. A qualidade da educação: perspectivas e desafios. CEDES, Campinas, v. 29, n. 78, p. 201-215, agosto de 2009. Disponível em $<$ http://www.scielo.br/scielo.php?script=sc i_arttext\&pid=S010132622009000200004\&lng=en\&nrm=iso >. http://dx.doi.org/10.1590/S010132622009000200004.

Acesso em: 14 de Mai. de 2020.

MARCHELLI, P. S.. Expansão e qualidade da educação básica no Brasil. Pesqui. São Paulo, v. 40, n. 140, p. 561-585, agosto de 2010. Disponível em

$<$ http://www.scielo.br/scielo.php?script=sc i_arttext\&pid=S0100-

$15742010000200013 \& \operatorname{lng}=$ en\&nrm=iso $>$. https://doi.org/10.1590/S0100-

15742010000200013 .

Acesso em: 14 de Mai. de 2020.

FREITAS, D. N. T. Avaliação da educação básica e ação normativa federal. Cad.

Pesqui., São Paulo, v. 34, n. 123, p. 663689, Dec. 2004 . Available from <http://www.scielo.br/scielo.php?script=sc i_arttext\&pid=S0100-

$15742004000300008 \& \operatorname{lng}=e n \& n r m=i s o>$. https://doi.org/10.1590/S0100-

15742004000300008.

Acesso em: 14 de Mai. de 2020.

ALVES, W.. Gestão escolar e o trabalho dos educadores: da estreiteza das políticas à complexidade do trabalho

humano. Educ. Soc., Campinas, v. 31, n. 110, p. 17-34, Mar. 2010. Available from

http://www.scielo.br/scielo.php?script=sci

_arttext\&pid=S0101-

$73302010000100002 \& \operatorname{lng}=e n \& n r m=i s o$. https://doi.org/10.1590/S0101-

73302010000100002.

Acesso em: 14 de Mai. de 2020.
DIAS, N. F. C.; MELAO, N. F. R. Avaliação e Qualidade: Dois Conceitos Indissociáveis na Gestão

Escolar. Tékhne, Barcelos, n. 12, p. 193-214, dez. 2009. Disponível em $<$ http://www.scielo.mec.pt/scielo.php?scrip $\mathrm{t}=$ sci_arttext\&pid=S1645-

99112009000200011\&lng=pt\&nrm=iso>.

Acesso em: 14 de Mai. de 2020.

COELHO, M. I. M. Vinte anos de avaliação da educação básica no Brasil: aprendizagens e desafios. Ensaio: aval.pol.públ.Educ., Rio de Janeiro, v. 16, n. 59, p. 229-258, June 2008

- Available from

http://www.scielo.br/scielo.php?script=sci _arttext\&pid=S0104-

40362008000200005\&lng=en\&nrm=iso. http://dx.doi.org/10.1590/S010440362008000200005.

Acesso em: 14 de Mai. de 2020.

FRANCO, C. O SAEB - Sistema de Avaliação da Educação Básica: potencialidades, problemas e desafios. Rev. Bras. Educ., Rio de Janeiro, n. 17, p. 127-133, Aug. 2001 . Available from $<$ http://www.scielo.br/scielo.php?script=sc i_arttext\&pid=S1413-

24782001000200010\&lng=en\&nrm=iso>. https://doi.org/10.1590/S141324782001000200010.

Acesso em: 14 de Mai. de 2020.

PERONI, Vera Maria Vidal; OLIVEIRA, Regina Tereza Cestari de; FERNANDES, Maria Dilnéia Espíndola. Estado e terceiro setor: as novas regulações entre o público e o privado na gestão da educação básica brasileira. Educ. Soc., Campinas, v. 30, n. 108, p. 761-778, Oct. 2009

. Available from $<$ http://www.scielo.br/scielo.php?script=sc i_arttext\&pid=S0101$73302009000300007 \& \operatorname{lng}=\mathrm{en} \& \mathrm{nrm}=\mathrm{iso}>$. http://dx.doi.org/10.1590/S010173302009000300007.

Acesso em: 14 de Mai. de 2020. 
NARDI, E. L.; SCHNEIDER, M. P.; RIOS, M. P. G. Qualidade na educação básica: ações e estratégias dinamizadoras. Educ. Real., Porto Alegre, v. 39, n. 2, p. 359390, June 2014. Available from http://www.scielo.br/scielo.php?script=sci arttext\&pid=S2175$\underline{62362014000200003 \& \operatorname{lng}=e n \& n r m=i s o} . \underline{\mathrm{h}}$ ttps://doi.org/10.1590/S217562362014000200003.

Acesso em: 14 de Mai. de 2020.

FACCI, M. G. D.; URT, S. C.; BARROS, A. T. F. Professor readaptado: a precarização do trabalho docente e o adoecimento. Psicol. Esc. Educ., Maringá , v. 22, n. 2, p. 281-290, Aug. 2018. Available from:

<http://www.scielo.br/scielo.php?script=sc i_arttext\&pid=S1413$85572018000200281 \& \operatorname{lng}=e n \& n r m=i s o>$. https://doi.org/10.1590/2175-

3539201802175546.

Acesso em: 17 de Mai. de 2020.

SAMPAIO, M. M. F.; MARIN, A. J. Precarização do trabalho docente e seus efeitos sobre as práticas curriculares. Educ. Soc., Campinas, v. 25, n. 89, p. 1203-1225, Dec. 2004

. Available from $<\mathrm{http}: / / \mathrm{www}$.scielo.br/scielo.php?script=sc
i_arttext\&pid=S0101$73302004000400007 \& \operatorname{lng}=e n \& n r m=$ iso $>$. http://dx.doi.org/10.1590/S010173302004000400007.

Acesso em: 17 de Mai. de 2020.

CHIRINEA, A. M.; BRANDAO, C. F. O IDEB como política de regulação do Estado e legitimação da qualidade: em busca de significados. Ensaio:

aval.pol.públ.Educ, Rio de Janeiro, v. 23, n. 87, p. 461-484, June 2015

- Available from $<$ http://www.scielo.br/scielo.php?script=sc i_arttext\&pid=S010440362015000200461\&lng=en\&nrm=iso $>$. https://doi.org/10.1590/S010440362015000100019.

Acesso em: 17 de Mai. de 2020.

FRANCO, A M. P.; MENEZES FILHO, N. Uma análise das classificações das escolas brasileiras com dados do SAEB. Estud. Econ., São Paulo, v. 42, n. 2, p. 263-283, junho de 2012. Disponível em $<$ http://www.scielo.br/scielo.php?script=sc i_arttext\&pid=S0101$41612012000200002 \& \operatorname{lng}=e n \& n r m=i s o>$. https://doi.org/10.1590/S010141612012000200002 . Acesso em: 17 de Mai. de 2020. 